\title{
Regionalizing International Criminal Law?
}

Charles Chernor Jalloh

Florida International University College of Law, charles.jalloh@fiu.edu

Follow this and additional works at: https://ecollections.law.fiu.edu/faculty_publications

Part of the Criminal Law Commons, and the International Law Commons

\section{Recommended Citation}

Charles Chernor Jalloh, Regionalizing International Criminal Law? , 9 Int'I Crim. L. Rev. 445 (2009).

Available at: https://ecollections.law.fiu.edu/faculty_publications/250 


\section{HEINONLINE}

Citation: 9 Int'l Crim. L. Rev. 4452009

Provided by:

FIU College of Law

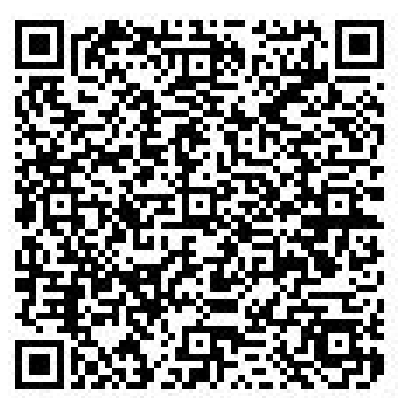

Content downloaded/printed from $\underline{\text { HeinOnline }}$

Mon Sep 19 11:52:39 2016

-- Your use of this HeinOnline PDF indicates your acceptance of HeinOnline's Terms and Conditions of the license agreement available at http://heinonline.org/HOL/License

-- The search text of this PDF is generated from uncorrected OCR text.

-- To obtain permission to use this article beyond the scope of your HeinOnline license, please use:

\section{Copyright Information}




\title{
Regionalizing International Criminal Law?
}

\author{
Charles Chernor Jalloh* \\ Assistant Professor of Law, University of Pittsburgh School of Law \\ Pittsburgh, PA, USA
}

\begin{abstract}
This article examines the initially cooperative but increasingly tense relationship between the International Criminal Court (ICC) and Africa. It assesses the various legal and political reasons for the mounting criticisms of the ICC by African governments, especially within the African Union (AU), following the indictment of incumbent Sudanese President Omar Hassan Al Bashir. The author situates the ICC within broader African efforts to establish more peaceful societies through the continent-wide AU. He submits that the ICC, by prosecuting architects of serious international crimes in Africa's numerous conflicts, could contribute significantly to the continent's fledgling peace and security architecture which aims to prevent, manage and resolve conflicts and to anticipate and avert crimes against humanity. On the other hand, the author suggests that the ICC also has much to gain from Africa, especially in these early years when it is seeking to become a functional court of law with global legitimacy. By undertaking independent, fair and credible prosecutions without alienating States Parties, the world criminal court is more likely to fulfill its mandate and to win over powerful hold outs, such as the United States, China, and India. This will help it co-opt the support necessary for its universal reach and future success. However, he cautions that given Africa's sensitive historical experience with foreign interventions, including the slave trade and colonialism, the international criminal justice regime anchored on the ICC may be undermined, or perhaps even falter, if it is perceived as having a biased, politicized or insensitive application to a single region of the world.
\end{abstract}

\section{Keywords}

Africa; International Criminal Court; African concerns about ICC

\footnotetext{
* B.A. (Guelph), LL.B., B.C.L. (McGill), M.St. and Chevening Scholar (Oxon); of the Bar of Ontario, Canada; formerly Associate Legal Officer, International Criminal Tribunal for Rwanda and the Legal Advisor/Duty Counsel to the Office of the Principal Defender, Special Court for Sierra Leone. I wish to thank various people for their excellent comments on an earlier draft, especially William A. Schabas, Joseph Rikhof, Janewa Osei-Turu and Alhagi-Marong. Errors and omissions are mine. E-mail: jallohc@gmail.com.
} 
We are not against international justice. It [just] seems that Africa has become a laboratory to test the new international law.

His Excellency Jean Ping, Chairperson, African Union Commission.'

Rwanda cannot be party to ICC for one simple reason ... with ICC all the injustices of the past including colonialism, imperialism, keep coming back in different forms. They control you. As long as you are poor, weak there is always some rope to hang you. ICC is made for A fricans and poor countries.

His Excellency Paul Kagame, President of the Republic of Rwanda. ${ }^{2}$

\section{Introduction}

On 2 February 1999, Senegal became the first country in the world to ratify the Rome Statute of the International Criminal Court (the Rome Statute). ${ }^{3}$ Senegal's speedy ratification symbolically capped Africa's early support for the idea of a permanent International Criminal Court (ICC or the Court) with jurisdiction over the "most serious crimes of concern to the international community as a whole." The historic ratification by the small West African state, from amongst a group of 120 countries that signed the Rome Statute at its adoption on 17 July 1998, demonstrates a keen awareness of the significance that the accomplishments of the ICC would imply for the world as a whole and for Africa in particular.

Indeed, as the representative of the Organization of African Unity (OAU) observed during the final five-weeks of the Rome negotiations, the continent of Africa had a special interest in the establishment of the ICC because its people had for centuries endured human rights atrocities such as slavery, colonial wars and other horrific acts of war and violence which continue today despite the continent's post-colonial phase. ${ }^{5}$ Furthermore, fresh memories of the tragic and "preventable" Rwandan genocide in 1994, in which the international community was forewarned about genocide but chose not to act, strengthened Africa's resolve to support the idea of an independent and effective international penal court that would punish, and hopefully deter, perpetrators of such heinous crimes in the

\footnotetext{
"BBC News, "Vow to pursue Sudan over "crimes", 27 Seprember 2008, online at: <http://news .bbc.co.uk/2/hi/africa/7639046.stm> (visited 15 May 2009).

2) D. Kezio-Musoke, 'Kagame tells why he is against ICC charging Bashir', Daily Nation, 3 August 2008, online ar: < htrp://allafrica.com/srories/2008081 20157.html> (visited 15 May 2009).

3) UN doc. AVCONF.183.9.

4) Preamble, ICCSt, para. four.

5) Professor T. Maluwa, Legal Adviser, OAU Secretariar, Statement at $6^{\text {th }}$ Plenary, 17 June 1998. See Official Records of the United Nations Diplomatic Conference of Plenipotentiaries on the Establishment of an International Criminal Court, UN doc. A/CONF.183/13 (Vol. II) 104, 115-118 at para. 116.

(5) Rwanda: The Preventable Genocide - The Report of the International Panel of Eminent Personalities to Investigate the 1994 Genocide in Rwanda and the Surrounding Events (Addis Ababa: OAU, 7 July 2000).
} 
future. ${ }^{7}$ Not surprisingly, the continent went on to play a significant and constructive role in the Rome negotiations which ultimately led to creation of the Court. ${ }^{8}$

Today, over a decade after the Rome Statute was adopted, African countries, many of which are either embroiled in devastating conflicts or newly emergent from them, have continued to invest their yearnings for peace and stability in the hope that the freshly minted ICC will become a success story, and one that will benefit them. As of writing, there are 108 States Parties to the Rome Statute. ${ }^{9}$ Of all the regions, Africa has generated the largest support base for the Court at 30 ratifying states. This constitutes over half of the continent's 52 countries. ${ }^{10}$ Thirteen additional African countries have signaled their support for the treaty through their signatures. Africa is followed by 25 states from Western Europe, 23 from Latin America and the Caribbean, 16 from Eastern Europe and 14 from Asia. However, the significance of the continent's strong endorsement of the ICC is not adequately reflected by the numbers alone. It is perhaps better captured by the reality that African states are likely to be the frequent users, or "repeat customers", for the Court because of a relatively higher prevalence of conflicts and serious human rights violations and a general lack of credible legal systems to address them.

There are currently four situations under formal ICC investigation. " Of those, three reflect the continent's wide embrace of the Court. Uganda, ${ }^{12}$ the Democratic

\footnotetext{
7) Maluwa, supra note 5 , at para. 116.

8) H. Jallow and F. Bensouda, 'International criminal law in an African Context', in $M$. du Plessis (ed.), African Guide to International Criminal Justice (Pretoria: Institute for Security Studies, 2008) pp. 15-54, at 41. See also P. Mochochoko, 'Africa and the International Criminal Court', in E. Ankumah and E. Kwakwa (eds.), African Perspectives on International Criminal Justice (Accra: Africa Legal Aid, 2005) and S. Maqungo, "The Establishment of the International Criminal Court: SADC's Participation in the Negotiations' 9 African Security Review (2000).

9) One hundred and thirty countries have signed the Rome Stature. See ICC, 'Status of Ratifications of the Rome Statute', online at: <http://www.icc-cpi.int/Menus/ASP/states+parties> (visited 15 May 2009).

10) The countries are as follows: Benin, Botswana, Burkina Faso, Burundi, Central African Republic, Chad, Comoros, Congo (Brazzaville), the Democratic Republic of the Congo, Djibouti, Gabon, Gambia, Ghana, Guinea, Kenya, Lesotho, Liberia, Madagascar, Malawi, Mali, Mauritius, Namibia, Niger, Nigeria, Senegal, Sierra Leone, South Africa, Tanzania, Uganda and Zambia, online at: <http://www.icc-cpi.int/statesparties.html> (visited 15 May 2009). Significantly, this list includes the regional powers Nigeria and South Africa.

11) In addition, the Prosecutor is currently conducting a preliminary analysis of various other situations. Three of those, namely Chad, Kenya and Ivory Coast, are in Africa while the others are from around the world including Afghanistan, Colombia, Georgia and Palestine. ICC Office of the Prosecutor, 'Frequently Asked Questions: Where is the Office of the Prosecutor currently active?' online at: <http://www2.icc-cpi.int/Menus/ICC/Structure+ of +the+Court/Office + of +the+ Prosecutor/FAQ/l> and 'Visit of the Palestinian National Authority Minister of Foreign Affairs, Mr. Riad al-Maliki, and Minister of Justice, Mr. Ali Khashan, to the Prosecutor of the ICC, 13 February 2009, online at: <http://www2.icc-cpi.int/NR/rdonlyres/4CC08515-D0BA-454D-A594446F30289EF2/280140/ICCOTP20090213Palestinerev.pdfs (visited 15 May 2009).

12) Referral submitted in December 2003. Decision to open investigation followed on 29 July 2004.
} 
Republic of Congo (DRC) ${ }^{13}$ and the Central African Republic (CAR), ${ }^{14}$ all of which are parties, were the first countries to break the ice of impunity by successively giving work to the ICC through so-called "self-referrals" of their respective situations for investigations and possible prosecution. ${ }^{15}$ Of course, the Court's jurisdiction is based on complementarity. This means that it is only where a state is "unwilling or unable genuinely to carry out the investigation or prosecution" that it can assert jurisdiction. ${ }^{16}$ While it could be argued that the African Article 14 referrals were made despite the fact that the states in question may have been willing and able to prosecute, by inviting the permanent court to investigate international crimes within their territories, those three nations put aside the sovereign pride that traditionally impeded state action towards punishment of gross humanitarian law violations. From an international treaty law perspective, they demonstrated good faith towards their Rome Statute obligations consistent with the edict pact sunt servanda in the Vienna Convention on the Law of Treaties (VCLT). ${ }^{17}$ They affirmed willingness, but acknowledged some inability, to address the international crimes being committed against their people within their territories. In so doing, Uganda, the CAR and the DRC waived complementarity and put themselves on the line to offer the first test cases to an untested court. ${ }^{18}$

Though obviously also motivated by other selfish reasons, for example, a desire to punish elusive adversaries or concerns about the political costs of unpopular domestic prosecutions, these self-referrals are still significant given that the Rome Statute applies equally to all persons without any distinction based on official capacity. ${ }^{19}$ Indeed, the ICC regime does not recognize any exception from prosecution or confer any immunity on public officials - whether heads of state, elected representatives or other government officials. Nor does it allow any military commanders, or persons acting as such, to evade prosecution for international offences committed by subordinates or others within their effective control. ${ }^{20}$ Therefore, by referring their situations to Court Prosecutor Luis Moreno-Ocampo for investigations, the leaders of those countries, for instance President Yoweri

\footnotetext{
13) Referral submitted in March 2004. Decision to open investigation followed on 5 July 2004.

14) Referral submitted on 7 January 2005. Decision to open investigation followed on 27 May 2007.

15) Referrals take place under Art. 14 ICCSt (Referral of a situation by a State Party). For commentary, see C. Kress, "Self Referrals" and "Waivers of Complementarity", 2 Journal of International Criminal Justice (2004) 944-6 and P. Gaeta, "Is the Practice of 'Self-Referrals" a Sound Start for the ICC?', 2 Journal of International Criminal Justice (2004) 951-52.

16) Art. 17(1)(a) ICCSt (Issues of admissibility).

17) (1979) 1155 UNTSt 331. Art. 26 states: Every treaty in force is binding upon the parties to it and must be performed by them in good faith.

18) On the idea of waiver of complementarity, see generally Kress, supra note 15.

(9) Art. 27 ICCSt. (Irrelevance of official capacity).

20) Art. 28 ICCSt. (Responsibility of commanders and other superiors).
} 
Museveni of Uganda whose army reportedly has a patchy record of compliance with the laws of war, rendered themselves and their military commanders more directly vulnerable to indictment and prosecution.

This is more than a mere theoretical possibility. In fact, the Prosecutor has already been criticized for singling out crimes allegedly committed by rebel or opposition leaders, while ignoring offences apparently perpetrated by government forces in places like Uganda and the DRC. ${ }^{21}$ For his part, Moreno-Ocampo has pledged to conduct impartial investigations and to prioritize cases of higher gravity. ${ }^{22}$ That said, his approach of initially targeting non-state actors is likely also driven by pragmatic considerations given the need for continued cooperation of the relevant national authorities to enable his work. Nevertheless, he may later charge others to show even-handedness and perhaps boost the legitimacy of his decisions.

Sudan is the fourth and currently last situation to be triggered. The United Nations Security Council (the Security Council) referred that nation to the ICC in Resolution 1593 (2005) pursuant to Article 13(b) of the Rome Statute. ${ }^{23}$ That provision empowers it, consistent with its Chapter VII power in the Charter of the United Nations, to ensure the maintenance of international peace and security, to refer non-parties for investigation and possible prosecution. ${ }^{24}$ The Sudan referral was recommended by a UN commission of inquiry which essentially found that international crimes were being committed in Darfur and should therefore be prosecuted. $^{25}$

Due to the Bush Administration's "aversion" 26 towards the Court, the United States of America (the U.S.) initially opposed the idea of referring Sudan to the Hague-based permanent court. However, it ultimately faced significant pressure not to veto the referral resolution after it failed to garner sufficient support within the Security Council for its proposed alternative - an establishment of

21) W.A. Schabas, 'Prosecurorial Discretion v. Judicial Activism', 6 Journal of International Criminal Justice (2008) 731-761, at 752-753.

22) ICC Office of the Prosecutor, 'Statement by Luis Moreno-Ocampo to the Fourth Session of the Assembly of State Parties', 28 November - 3 December 2005 at 3, online at: <htrp://www.icc-cpi .int/NR/rdonlyres/169D124D-A2C3-444B-B498-A3FFD8CF177C/277382/LMO_20051128 English 1.pdfs (visited 15 May 2009) (noting that, given the gravity of the crimes committed by the LRA, it was clear that 'we must start with the LRA').

23) SC Res. 1593, 31 March 2005.

24) Sudan signed the Rome Statute on 8 September 2000 but has not yet ratified it. While unlikely to do so now, it is still bound to avoid conduct that would defeat the object and purpose of the treaty.

25) Report of the International Commission of Inquiry on Darfur to the United Nations SecretaryGeneral Pursuant to Security Council Resolution 1564 of 18 September 2004 (Geneva: UN, January 25, 2005), at paras. 569-589, 647-649.

26) 'U.S. Fiddles Over ICC While Darfur Burns: U.N. Security Council Should Reject U.S. Scheme for Ad Hoc Court', Human Rights Watch, online at: <http://hrw.org/english/docs/2005/01/31/ usint 10091_txt.htm> (visited 15 May 2009). 
an ad hoc tribunal for Sudan. ${ }^{27}$ The U.S. abstained from the vote on the controversial resolution and has since become increasingly favorable to the prosecution. $^{28}$

Africa's strong backing for the Court has not been limited to the continent's governments. Confronted with a slew of unaccountable regimes and outright dictatorships that pay little or no heed to basic human rights principles, African civil society - individuals and non-governmental organizations (NGOs) endorsed early on the idea of a standing international penal court. Indeed, many from the continent played an important role advancing the objectives of the unprecedented global network that gave extra momentum to the conclusion of the Rome Statute. This was done primarily through advocacy at home, but also through the influential and unprecedented NGO Coalition for the Establishment of an International Criminal Court. As part of this, activists from the continent and their counterparts in other parts of the world mobilized shame to stir the conscience of their governments towards agreement on contentious issues. The end product, while perhaps falling short of the stated preferences of individual advocacy groups over the years of negotiations, was a more robust instrument than even the ICC's strongest supporters could sensibly have hoped for. ${ }^{29}$

Once the treaty was adopted, African and other human rights NGOs quickly transformed themselves into an effective global campaign for swift achievement of the 60 ratifications required for the Rome Statute to enter into force. This, of course, breathed life into the ICC in July 2002 - much sooner and more dramatically than anyone could have reasonably anticipated. ${ }^{30}$ Afterwards, many of those same organizations supported the work of the Preparatory Commission to assist in developing important ancillary legal instruments, for example, the Court's rules of procedure and evidence and the elements of crimes. ${ }^{31}$

\footnotetext{
27) See, e.g., Human Rights Watch, Letter to U.S. Secretary of State Designate Dr. Condoleezza Rice dated 21 January 2005, 'ICC Best Chance for Justice in Darfur: U.S. Should Support or Abstain from Security Council Referral of Darfur to the International Criminal Court', online at: <http:// hrw.org/english/docs/2005/01/21/sudan 10090.htm> (visited 15 May 2009).

28) See, e.g., L. Condorelli and A. Ciampi, 'Comments on the Security Council Referral of the Situation in Darfur to the ICC', 3 Journal of International Criminal Justice (2005) 590-97.

29) W.R. Pace and M. Thieroff, 'Participation of Non-Governmental Organizations', in R.S. Lee (ed.), The International Criminal Court: The Marking of the Rome Statute - Issues, Negotiations, Results (The Hague: Kluwer Law International, 1999) pp. 391-398, at 395. Over 20 African NGOS were invited to participate in the Rome Statute negotiations pursuant to GA Res. 52/60, 15 December 1997. Participation included attending plenary and formal meetings of subsidiary bodies at the conference except the drafting group, receiving official documents, providing material to delegates and by addressing certain open and closed sessions of meetings. See Note by the [UN] Secretary-General, Non-Governmental Organizations Accredited to Participate in the Conference, UN doc. A/CONF.183/INF/3, 5 June 1998.

30) W.A. Schabas, An Introduction to the International Criminal Court (2 $2^{\text {nd }}$ edn., Cambridge: CUP, 2004), p. 19.

31' Pace and Thieroff, supra note 29, at 397.
} 
Today, African civil society seems to have entered a third phase of advocacy whereby it now leverages prior contacts within governments to not only lobby for the remaining ratifications, but also adoption of the necessary legislation and domestic programs to give effect to their Rome Statute obligations. Overall, given the serious governance deficit on the continent, local and international human rights NGOs played an important role sensitizing political leaders to the potential benefits of a strong court for Africa. They therefore seem set to continue influencing the evolution of international criminal justice issues on the continent in the future.

It is against this backdrop that this article examines the recent controversy about the ICC's current work in Africa, a quintessential example of the proverbial moving target, in light of its global mandate to prosecute those most responsible for serious international crimes and concerns expressed by various African leaders. In this regard, I argue that current trends indicate that some African states are tempted, based more on hasty political assessments than on sober legal analysis of the Rome Statute, to throw out the ICC baby with the bath water. I submit that they should not. Overall, while conceding that some AU criticisms of the Court's current prosecutorial practice may be justified, I maintain that it would not be in Africa's best interest to ostracize the permanent ICC as an institution at this early stage of its lifespan. This is particularly so given that the bulk of the apparent African disquiet seems to stem largely from the actions of only one of its four organs. In this vein, I situate the Court within Africa's broader efforts to build more peaceful and stable societies. I then highlight some of the gains that can accrue from the ICC for the African Union's (AU) fledgling peace and security "architecture" which aims to prevent, manage and resolve conflicts through an early warning system that even authorizes military intervention to anticipate or avert the commission of grave international crimes.

On the other hand, I suggest that the Court, especially its prosecutor, must take $\mathrm{AU}$ criticisms of its work more seriously than appears to be the case now. In this regard, unlike conventional wisdom which portrays it as the generous giver and Africa as its hapless beneficiary, I argue that the ICC also stands to reciprocally benefit from the continent, especially in these early years when it is seeking to become a functional court of law with global legitimacy. ${ }^{32}$ In my view, the Court today needs Africa as much as Africa needs the Court. However, I submit that it should not be construed as the International Criminal Court for Africa, or the African (International) Criminal Court. In fact, I maintain that the emerging international criminal justice system, which is anchored on the world's only

\footnotetext{
32) In orher words, I go beyond the suggestion that the relationship is a one-way street and that it is only Africa that needs the ICC. See, e.g., D. Iber, 'Africa Needs Judicial Body', Pan African News Agency, 4 October 1999 (arguing that Africa, with its numerous internal armed conflicts, is in 'desperate need' for an international criminal court).
} 
permanent penal court, offers a "win-win" prospect for both sides. Nevertheless, I caution that given the continent's sensitive historical experiences with foreign interventions, especially the trans-Atlantic slave trade and colonialism, the international criminal justice regime that the ICC represents may be undermined, or perhaps even falter, if it is perceived as having a biased, politicized or insensitive application to this sole and relatively more vulnerable region of the world.

For the sake of clarity, my argument is not rooted in politics. Nor is it a moral case for the powerful ICC to give extra attention to a powerless and complaining Africa. Rather, it is a legal argument based on the Court's mandate articulated in the Rome Statute, especially the principle of complementarity, which recognizes and underscores that measures taken at the national level are the key to the prevention and punishment of international crimes. In some respects, it is a reminder for African governments that in the long run they are better off in a world with, rather than without, an independent and effective ICC.

By the same token, it is a call for pragmatism on the part of the Court since, as a multilateral treaty-based body, no matter how powerful and unprecedented it may be, it does not have a standing police force or army to enforce its orders. Thus, it is completely dependent upon the cooperation of its States Parties and the goodwill of many others to carry out its work - whether to investigate situations, collect evidence, detain suspects, execute arrest warrants, facilitate witness testimony, enforce subpoenas for documents, judicial orders, sentences, and so on. In fact, while states have generally cooperated with them, the experience of the United Nations (UN) ad hoc criminal tribunals amply demonstrate that if national authorities refuse to assist such courts, international criminal justice will become paralyzed and unable to fulfill its necessary and expanding role in international society. ${ }^{33}$ This Achilles heel is exposed by the elaborate provisions in the constitutive instruments of the various international penal courts, including the Rome Statute, purporting to compel state cooperation. International prosecutors, whose most routine work is only possible because of state support, know this reality all too well and have therefore repeatedly emphasized that support from

\footnotetext{
33) This dependence on state cooperation is starkly illustrated by an important case in the UN criminal tribunal for Rwanda. Following an Appeals Chamber decision to release Jean BoscoBarayagwiza for abuse of process on the part of the Prosecutor, Rwanda suspended its cooperation and took certain steps to show its displeasure, including denials of visas and access to the country. About 16 wirnesses were denied permission to travel to the seat of the tribunal in Arusha, Tanzania to testify, threarening to ground judicial proceedings to a halt. An application for reconsideration was duly lodged by the Prosecutor based on alleged new facts about the circumstances in which the problematic detention of the accused had taken place. The judges revisited the issue and ordered Barayagwizas trial. Rwanda resumed its cooperation. The accused was later convicted. See Prosecutor v. Jean-Bosco Barayagwiza (ICTR-97-19-AR72), 'Decision on Prosecutor's Request for Review or Reconsideration', Appeals Chamber, 31 March 2000, para. 34 and Declaration of Judge Rafael Nieto-Navia, paras. 1-8.
} 
national jurisdictions is one of the pillars on which the future of international criminal justice depends. ${ }^{34}$

This article is divided into six parts and a conclusion. Besides the Introduction (Section 1), Section 2 starts by situating Africa within its broader historical context. It sketches how the prevalence of internecine conflicts and gross human rights violations have led to an African pre-occupation with the question of how to build more peaceful societies after conflict and mass atrocity. Section 3 then turns to the continent's more recent efforts to stem serious international crimes. It is argued that the establishment of the $A U$ and its ongoing efforts to build a peace and security architecture with primary responsibility to prevent, manage and resolve African crises and conflicts are integral parts of this trend. Section 4 briefly considers the main international and hybrid tribunals which preceded and, in many ways paved the way for the creation of the permanent ICC, to demonstrate the strong African role in their founding and in the emergence of an international criminal justice system. Section 5 will then briefly highlight some of the key concerns that have been expressed regarding the ICC's recent work in Africa. Focusing on the fallout from the Sudan situation and the Bashir arrest warrant, I endeavor to show why some African leaders now perceive the Court as nothing more than the new imperialism masquerading as international rule of law. ${ }^{35}$

To challenge this notion, I maintain in Section 6 that impunity for egregious international crimes seems to no longer be available in Africa given the various mechanisms that the $A U$ has sought to develop to counter it, including the first regional implementation of the so-called right of humanitarian intervention. In this context, and considering their respective positions currently, I propose that both the continent and the ICC share a mutual interest in addressing heinous international crimes. It is therefore logical for the two sides to closely collaborate. In this vein, I suggest that there is mutual gain to be reaped, and conversely a "mutual vulnerability" to be confronted, should they fail to do so. ${ }^{36}$ Section 7 then

34) See, e.g., Special Court for Sierra Leone, Press Release, "War Crimes Prosecutors Meer in Freetown', 27 June 2005 (noting that '... the tribunals are greatly reliant on the cooperation of national states', concluding that '...the tribunals cannot succeed without the firm commitment of sovereign states to discharge their legal and treaty obligations ... State cooperation with the international criminal tribunals is one of the pillars upon which the future development of international law depends.')

35) C. Jalloh, 'The Law and Politics of the Charles Taylor Case', Canadian Council on International Law Web Bulletin, April 2006, online at: <http://www.ccil-ccdi.ca/index.php?option=com_content \&task=view\&id=165\&Itemid=76> (visited 15 May 2009) (observing, in passing, that Africa was the only scene of investigations and the first arrest warrant by the ICC; warning that a failure to address perceptions that international criminal law is being built on the back of Africans may have profound implications which could undermine the legitimacy of the emerging international criminal justice system).

36) This phrase appears to have been first coined within the context of development theory by J. Nef, Human Security and Mutual Vulnerability. The Global Political Economy of Development and 
examines some key legal and political challenges that appear to undermine progress towards complete trust between the two sides. It is submitted that as these issues are resolved over time, there will likely be more predictability and therefore less tension in relations between Africa and the Court. Finally, in the conclusion, I summarize my central arguments and provide a tentative assessment of the broader implications of the current impasse for the ICC and the continent.

\section{Background - The State of Modern Africa}

Following centuries of foreign domination, first during the trans-Atlantic slave trade and then under colonialism, the late 1950s and early 1960s ushered in an era of political independence for most African countries. However, the hopes of millions of people on the continent that political independence would translate into greater prosperity, stability and development were dashed as the decades wore on. Worse, many states started exhibiting features that have led one Nigerian scholar to describe Africa as "a continent in perpetual turmoil." ${ }^{37}$

As is widely acknowledged, no single internal factor has contributed more to the continent's malaise than the scourge of conflict. ${ }^{38}$ Indeed, according to the UN, since 1970, well over 30 wars have been fought in Africa. Of these, the vast majority were within, as opposed to between, states. ${ }^{39}$ The continent has thus become the most conflict affected and conflict prone region in the world. In this regard, between 1980 and 1994, 10 of the 24 most war tormented countries were in Africa. ${ }^{40}$ Well over a decade later, by 2007 , the region still played generous host to the majority of the world's conflicts. ${ }^{41}$ The scale and nature of these generally

Underdevelopment (2nd edn., Otrawa: IDRC, 1999), 13. The idea was subsequently articulated by I. Head, On a Hinge of History: The Mutual Vulnerability of South and North (Toronto: University of Toronto Press, 1991).

37) $O$. Oko, 'The Challenges of International Criminal Prosecutions in Africa', 31 Fordham International Law Journal (2008) 343-414, at 343.

38) See, e.g., the Preamble to the Constitutive Act, para. 9; Peace and Security Protocol, para. 10; the Declaration on the Political and Socio-Economic Situation in Africa and the Fundamental Changes Taking Place in the World, Summit of the Heads of State and Government, Addis Ababa, Ethiopia, July 1990.

39) Report of the Secretary-General to the United Nations Security Council: The causes of conflict and the promotion of durable peace and sustainable development in Africa, UN doc. A/52/871-S/1998/318, 16 April 1998, at para. 4.

411) Cabinet Sub-Committee on Conflict Prevention in Africa, 'Causes of Conflicts in Africa', Consultation Document - March 2001, online at: <http://www.dfid.gov.uk/pubs/files/conflictafrica.pdf> (visited 15 May 2009).

41) L. Harbom and P. Wallensteen, Uppsala Conflict Data Program, 'Frequently Asked Questions: How many conflicts were there in the world in 2007?', online ar: <http://www.pcr.uu.se/research/ UCDP/links_faq/faq.htm\#4> (visited 15 May 2009). 
vicious conflicts have directly or indirectly affected the lives of millions of people, many of whom have been displaced from their homes and forced to abandon the basis of their already impoverished livelihoods.

With the conflicts have come extreme violence and the deliberate targeting of civilians, rather than armies, and in some cases, entire ethnic groups. Countries like Angola, Burundi, Congo, Liberia, Mozambique, Rwanda, Sierra Leone, Somalia, Sudan and Uganda became household names that evoked memories of barbarous acts, intractable violence, and ultimately, partial or complete collapse of state institutions, and sometimes, even the state itself. Ruthless military dictatorships, famine, abject poverty, barbaric civil wars in which civilians were not just fair game but the only game, widespread human rights abuses, including the commission of serious international crimes, have all regretrably become enduring features on the continent. Africans, ever so generous, supplied ample examples of the conditions that political scientists, such as Robert Kaplan, used to apocalyptically warn about the "coming anarchy" on the continent and elsewhere. ${ }^{42}$

In seeking to address the momentous challenges facing the continent, it became evident from Africa's experience between the immediate post independence period in the 1960s, and the end of the Cold War in the early 1990s, that the continent and its people cannot rely on the UN or the "international community" to solve its numerous crises. Overall, a slow response, or more often no response, characterized international policy towards the continent. ${ }^{43}$ In fact, some African countries, instead of cashing in the expected post-independence peace and economic dividends, became scenes of proxy wars where superpower rivalries played out; often, with devastating consequences for local populations. ${ }^{44}$ Furthermore, for Africa, the East-West stalemate that stymied the Security Council during the Cold War essentially transformed it into the Insecurity Council, especially on burning issues of human security.

Yet, even after the world bid farewell to communism, the UN seemed unable to discharge its function of ensuring the collective peace..$^{45}$ It consequently was

\footnotetext{
42) R. Kaplan, The Coming Anarchy: Shattering the Dreams of the Post-Cold War (New York: Random House, 2000).

43) See A.M. Kambudzi, 'The International Criminal Court and Africa: The AU and the ICC', in M. du Plessis and A. Louw (eds.), The Investigation and Prosecution of 'Core International Crimes' and the Role of the International Criminal Court in Africa (Pretoria: Institute for Security Studies, 2007) 27-39, at 29.

44) These rivalries played out in the Horn of Africa and Southern Africa where the two power blocs had strategic interests. Proxy wars were fought in the region. For example, South Africa attacked Angola in 1975 while Somalia invaded Ethiopia in 1977.

45) A. Cassese, 'International Criminal Justice: Is it Really so Needed in the Present World Community?', Public Lecture (London School of Economics) 13 November 2001, online at: <http://www.lse.ac.uk/Deprs/global/Publications/PublicLectures/PL_InternationalCriminal Justice.pdf (visited 15 May 2009) (arguing that a 'striking feature' of international relations today is that the UN Security Council has proved unable to 'solve major international crises').
} 
unable to meaningfully assist African nations to stem the tide of violence and gross human rights abuses spawned by the continent's incessant conflicts. Worse, Africa's own home grown OAU, founded with high expectations that it will swiftly deliver continental unity, got caught up in a faulty logic that exalted extremist versions of sovereignty and the principle of non intervention in the internal affairs of its member states. While it scored occasional successes in some areas, notably through support for national liberation struggles especially the fight against apartheid, it failed to make a lasting impact in alleviating the myriad complex emergencies facing the continent.

In the economic arena, Africa became the only continent with zero growth in three decades. As the OAU nailed its own coffin, it bequeathed conditions that would much later prompt British Prime Minister Tony Blair to characterize Africa, in a campaign for increased G-8 aid to the continent, "as a scar on the conscience of the world." ${ }^{46}$ Blair urged the industrialized countries to play doctor and "heal" the wounds of Africa. ${ }^{47}$ Some called his statement a spin doctoring exercise. Others, more cynical, just saw another outgoing Western leader shopping for a legacy cause.

\section{The Emerging African Peace and Security Architecture}

After the OAU's demise, Africa's multifaceted human security challenges naturally featured high on the agenda of the continent's leadership. Within the framework of the new $\mathrm{AU}$, the stated objective has been to promote peace, security and stability on the continent based on the understanding that this is the only way Africa can protect the well being of her peoples and their environment as well as create conditions conducive to sustainable economic growth and development. ${ }^{48}$ It has therefore started building a so-called continental peace and security "architecture" by creating interlocking institutional mechanisms aimed at preventing, managing and resolving crises and conflicts. ${ }^{49}$

Two overarching ideas underpin the fledgling regime. First, the early detection, intervention and management of crises would help prevent their escalation into full blown conflict. Second, in the long term, the best guarantor of peace is the creation of a transparent democratic, political and economic environment meeting the needs of all individuals and groups within society. The AU has gone so far as to pledge to undertake the immense, costly and unprecedented task of post

461) C. McGreal, 'Blair Confronts Scar on World's Conscience', The Guardian, 7 February 2002.

47) The Independent, 14 August 2004.

48) Preamble, Constitutive Act, para. 8.

4") Kambudzi, supra nore 43 , at 30. 
conflict reconstruction, peace building and revitalization of state institutions in its member states experiencing conflict. ${ }^{50}$

This ambitious plan was outlined mainly in the Protocol Relating to the Establishment of the Peace and Security Council of the African Union (Peace and Security Protocol) adopted in Durban, South Africa on 9 July 2002. That instrument established the Peace and Security Council (PSC) as the permanent mechanism for conflict prevention, management and resolution on the continent under Article 2. Though primarily responsible for the region's efforts in the area of human security, the PSC was conceived as part of a larger and integrated peace maintenance and peace enforcement machinery. It will therefore not operate in clinical isolation from other $\mathrm{AU}$ organs and initiatives.

In fact, Article 2(2) of the Peace and Security Protocol envisages that the PSC shall collaborate with and complement other components of the architecture, in particular, the Chairperson of the AU Commission; a five member Panel of the Wise; the Continental Early Warning System; the African Standby Force and a Special Fund. Moreover, the AU's broader peace and security framework puts into play the Regional Mechanisms for Conflict Prevention, Management and Resolution and a host of additional human rights related treaties and instruments. ${ }^{51}$ Taken together, these suggest a shift from the continent's paradigmatic focus on conflict resolution to a comprehensive approach to human security which factors political, economic, social and other considerations into the formula for peace and stability. ${ }^{52}$

Significantly, in a provision that seems to signal a radical break from the informal "scratch my back and I scratch yours" OAU policy that condoned gross human rights violations committed by African governments, the Constitutive Act of the African Union (Constitutive Act) gave the AU the right in Article 4(h): "to intervene in a Member State pursuant to a decision of the Assembly in respect of grave circumstances, namely: war crimes, genocide and crimes against humanity" ${ }^{53}$

This clause was reiterated in Article $7(1)(e)$ of the Peace and Security Protocol which empowered the Council to:

recommend to the Assembly, pursuant to Article 4(h) of the Constirutive Act, intervention, on behalf of the Union, in a Member State in respect of grave circumstances, namely war crimes, genocide and crimes against humanity, as defined in relevant international conventions and instruments; ${ }^{54}$

\footnotetext{
50) Arts. 3(a)(Objectives) and 14 (Peace building), Peace and Security Protocol.

51) These include, for instance, the AU Non-Aggression and Common Defence Pact, adopted by the 4th Ordinary Session of the Assembly of the Union, Abuja, Nigeria (January 2005).

52) AU Commission Conflict Management Division, Meeting the Challenge of Conflict Prevention in Africa: Towards the Operationalization of the Continental Early Warning System (Addis Ababa: AU, 2008), Foreword.

53) Emphasis added.

54) Emphasis added.
} 
The common logic of these provisions is the AU's recognition, stated in Article 4(O) of the Constitutive Act, that there ought to be: 'respect for the sanctity of human life, condemnation and rejection of impunity and political assassination, acts of terrorism and subversive activities'.

Importantly, the "sanctity of human life" and "rejection of impunity" can be given concrete effect to protect vulnerable populations through the AU's unilateral deployment of the African Standby Force in "grave circumstances" or, alternately, at the "request of an AU Member State" to restore stability as per Article $13(C)$ of the Peace and Security Protocol. Through the entrenchment of these provisions into the AU's primordial instruments, the continent has become the first region in the world to provide a specific legal basis for military intervention during conflict in order to protect vulnerable civilians. In this way, despite obvious resource shortages that would pose serious challenges for implementation, it has paved the way for the first regional implementation of the much vaunted doctrine of "Responsibility to Protect".ss

Beyond these provisions, which constirute the main pillars of the AU's budding peace and security architecture, it was obvious that the impoverished Africa could not go it alone if it is to successfully address the continent's complex and multi faceted post-Cold War emergencies. African governments therefore undertook in the Constitutive Act as well as in the Peace and Security Protocol to engage other governments and civil society, international organizations, for example, the UN, as well as other external entities that could assist it to realize its human security objectives. ${ }^{56}$ In relation to the Court, these instruments open up an avenue for mutually beneficial AU-ICC cooperation on issues ranging from technical cooperation to concrete measures combating impunity. Indeed, until recently, there were high level discussions about a Memorandum of Understanding between the two institurions. ${ }^{57}$ The recent controversies regarding the Sudan situation have slowed down the AU apperite for all things ICC. So it has inevitably tempered enthusiasm for those discussions.

\footnotetext{
55) The doctrine of Responsibility to Protect (R2P) aims to balance concerns about state sovereignty and the imperative to act, if need be with force, to halt genocide and crimes against humanity. See The Responsibility to Protect: Report of the International Commission on Intervention and State Sovereignty (Ottawa: ICISS, 2001) online at: <http://www.iciss.ca/pdf/Commission-Report.pdfs (visited 15 May 2009). R2P was endorsed by SC Res. 1674, 28 April 2006 on the prorection of civilians in armed conflict and GA Res. 60/1, 24 October 2005 setting out the World Summit outcome. For more on the R2P and the AU, see $K$. Powell, 'The African Union's Emerging Peace and Security Regime: Opportunities and Challenges for Delivering on the Responsibility to Protect', May 2005 Working Paper (The North-South Institute), online at: <http://www.nsi-ins.ca/ english/pdf/responsibility_protect_africa.pdf> (visited 15 May 2009).

${ }_{5(1)}$ Art. 13(C), Constitutive Act; Arts. 17(4) and 20, Peace and Security Protocol.

`7) Kambudzi, supra note 43, at 35-37.
} 


\section{The ICC as the Anchor of the Emerging International Criminal Justice System}

Africa's security environment is probably the worst when compared to other regions. But it is by no means unique. In fact, with the end of the Cold War, the international community witnessed, and continues to witness, the rise or revival of destructive variants of nationalism, religious fundamentalism and ethnic hatred, all of which stoked old animosities or spawned new ones and, ultimately, gave way to new forms of violence specifically, terrorism and ethnic cleansing. ${ }^{58}$ Confronted with these problems, states and the international community are increasingly compelled to act to address mass atrocities. The question no longer seems to be whether, but rather how, to respond to gross human rights violations. In this regard, according to Cassese, we can observe in deployment various "fallback solutions" developed by the international community to tackle such problems. ${ }^{59}$ These solutions can be discerned at the national and the international levels, and sometimes, at the intersection of the two.

First, national courts, for example those in the U.S., are increasingly willing to invoke jurisdictional grounds like territoriality or nationality. Second, domestic courts are routinely assuming the duty to confront atrocities perpetrated abroad through civil proceedings and awards of financial compensation to victims of human rights atrocities. Third, states are nowadays concluding treaties, such as the 1984 UN Convention Against Torture, which provide for the exercise of universal jurisdiction by their local courts with the attendant obligation to prosecute or extradite suspected perpetrators. Fourth, states are increasingly resorting to truth commissions to address odious crimes of the past, especially in Latin America and Africa. Fifth, a range of international courts and human rights treaty monitoring bodies, whether the European Court of Human Rights or the InterAmerican Commission of Human Rights, have jurisprudentially extended their jurisdiction to cover crimes perpetrated abroad by officials of state parties to their founding treaties. In respect of the continent, there have been attempts to bolster the work of the African Commission on Human and Peoples' Rights. These include the adoption of a new protocol with the view to the creation of a more robust and binding African human rights court mechanism. This is in addition to an increasing number of sub-regional courts of justice with competence to hear human rights cases in east, west and southern Africa.

Finally, and more relevant to our purposes here, the UN and the international community have, in the wake of shocking atrocities in specific conflicts around the world, sought to prosecute the planners and architects of those crimes,

58) A. Cassese, International Criminal Law (1 ${ }^{\text {st }}$ edn., Oxford: OUP, 2003), 3.

59) Ibid. at 5-14. 
principally genocide, crimes against humanity and war crimes. Accordingly, in 1993 and again in 1994, the Security Council invoked, for the first time, its Chapter VII powers to establish two ad hoc International Criminal Tribunals for the former Yugoslavia and Rwanda respectively (ICTY and ICTR).

At first blush, the international criminal tribunals appear to be part of an impressive ready-made international post conflict toolkit. However, it has been suggested that they are in fact merely substitutes for the failures to take concrete action to prevent or stop those tragedies. ${ }^{60}$ Some have even argued that those courts were designed to assuage the guilty conscience of the international community in the face of its impotence when confronted with ethnic cleansing in the Balkans and genocide in Rwanda. ${ }^{61}$ Whatever the case, at the request of the relevant governments, the UN has subsequently supported the creation of international or internationalized courts notably, the Special Court for Sierra Leone (SCSL) and Extraordinary Chambers in the Courts of Cambodia. ${ }^{62}$ Similarly, it also facilitated the establishment of war crimes panels in the national courts of East Timor and Bosnia. ${ }^{6.3}$

All these courts have, to varying degrees and each in their own way, contributed to settling the norm of individual accountability for serious international crimes at the international level. ${ }^{64}$ Nevertheless, their statutory mandates limited prosecution to specific crimes, committed within specific time frames, within specific territories. These limitations in their founding instruments notwithstanding, the ad hoc tribunals have been generally criticized, among other things, as slow and expensive relative to their number of trials, incurring costs amounting in the billions of dollars. ${ }^{65}$ This has since led the Security Council to require them

\footnotetext{
(11) See comments of the Rwandese Representative to the Security Council, UN doc S/PV.3453, 1994 at 14 and S.R. Ratner and J.S. Abrams, Accountability for Human Rights Atrocities in International Law: Beyond the Nuremberg Legacy (2 ${ }^{\text {nd }}$ edn., Oxford: OUP, 2001), at 191 and 201.

(1) H.J. Steiner and P. Alston, International Human Rights Law in Context: Law, Politics, Morals (2nd edn., Oxford: OUP, 2000), at 1155.

62) The UN has more recently also supported the establishment of a Special Tribunal for Lebanon. However, that is an internationalized court solely addressing common crimes under Lebanese law. For a thorough overview and key challenges, see the November 2007 symposium issue on the Lebanon Tribunal by the Journal of International Criminal Justice.

63) For an overview of the origins, establishment and issues confronting those courts, see W.A. Schabas, The UN International Criminal Tribunals: The former Yugoslavia, Rwanda and Sierra Leone (Cambridge: CUP, 2006); C.P.R. Romano et al., (eds.), Internationalized Criminal Courts: Sierra Leone, East Timor, Kosovo and Cambodia (Oxford: OUP, 2004).

(4) For discussions of their contributions, see, e.g., E. Mose, 'Main Achievements of the ICTR', 3 Journal of International Criminal Justice (2005) 920; C.C. Jalloh, "The Contribution of the Special Court for Sierra Leone to the Development of International Law', 15 African Journal of International and Comparative Law (2007) 165-207; L.J. van den Herik, The Contribution of the Rwandan Tribunal to the Development of International Law (Leiden: Martinus Nijhoff, 2005) and G. Mettratux, International Crimes and the Ad Hoc Tribunals (Oxford: OUP, 2005).

65) See, e.g., R. Zacklin, 'The Failings of Ad Hoc International Tribunals', 2 Journal of International Criminal Justice (2004) 541-545, at 545 (concluding that the ad hoc tribunals have been 'too costly,
} 
to adopt completion strategies, which include provisions for the transfer of certain cases to willing national courts for prosecution. ${ }^{66}$ It was envisaged that this would enable them to wrap up their work within a few years. A major concern that has since been expressed from both sides of the adversarial divide within the tribunals is that the completion strategies risk turning into completion tragedies with a seeming rush to closure that could undermine the fairness and legitimacy of the remaining trials, and possibly even tarnish the legacy of those institurions. ${ }^{67}$

Against this backdrop, it should be obvious that the advent of the ICC is an important institutional development in the evolution of international criminal law. With a mandate over genocide, crimes against humanity, war crimes and the additional and all important crime of aggression (once that crime is eventually defined), the Court is expected to leverage economies of scale, the principle of complementarity and its permanency to ensure greater accountability for certain crimes in a manner hitherto thought impossible. As the world's only permanent international penal tribunal, the existence of the ICC theoretically renders future ad hoc courts unnecessary. Indeed, many had hoped that creation of a standing court would, among other things, help ensure greater consistency in the application of international criminal justice by removing or at least distancing it from the vagaries of Security Council politics. That did not happen as a role was ultimately carved out in the Rome Statute for that body to refer and defer situations. With hindsight, this involvement of a political body in a judicial process has now come to haunt the Court, as the Sudan controversy starkly demonstrates.

In any case, recent experience with the inauguration of an internationalized Special Tribunal for Lebanon suggests that there may be compelling reasons for the UN and the international community to do otherwise in specific situations. Be that as it may, by the time the existing ad hoc courts shut down in a few years, the ICC may be the last court standing. It will therefore remain as the permanent anchor of the emerging international criminal justice system.

too inefficient and too ineffective'; and that they reflect an approach that is 'no longer politically or financially viable.')

${ }^{66)}$ For an overview of the transfer process in relation to the Rwanda Tribunal, see A. Marong, C.C. Jalloh, and D. Kinnecome, 'Concurrent Jurisdiction and the ICTR: Should the Tribunal Transfer Cases to Rwanda', in E. Decaux, A. Dieng and M. Sow (eds.), From Human Rights to International Criminal Law: Studies in Honour of an African Jurist, the Late Judge Laity Kama (Leiden: Martinus Nijhoff, 2007) pp. 159-201.

${ }^{67)}$ See the issue containing the workshops 'A Critical Look at Ad Hoc Tribunals' Completion Strategy: Open Questions and Prospects for the Future', 6 Journal of International Criminal Justice (2008) 681-709. See comments by P. Murphy and M.B. Harmon offering defence and prosecution perspectives respectively. Cf. response by Judge Erik Møse, the former President and Vice-President of the Rwanda Tribunal. 


\section{5. "[M]isuse of Indictments against African leaders": Changing Tone or Political Rhetoric?}

Adopted amidst much fanfare on 17 July 1998, the Rome Statute entered into force on 1 July 2002. The ICC was universally acclaimed as an historic milestone, including by African governments and civil society. Indeed, as Kofi Annan, then UN Secretary-General put it, the Court's establishment was "a gift of hope to future generations, and a giant step forward in the march towards universal human rights and the rule of law." ${ }^{88}$ Annan, a Ghanaian diplomat not known for hyperbole, subsequently proclaimed the ICC the "missing link in the international justice system." ${ }^{69}$

Just over a decade later, the Court has come under serious criticism from various quarters in Africa. Professor Mamood Mamdani, a respected Ugandan scholar, has eloquently captured this sentiment by arguing that notwithstanding its name, the "ICC is rapidly turning into a Western court to try African crimes against humanity." 70 To him, "the realization that the ICC has tended to focus only on African crimes, and mainly on crimes commitred by adversaries of the United States, has introduced a note of sobriety into the African discussion" and fuelled concerns about a "politicized justice" and even bigger questions about the "relationship between law and politics". ${ }^{71}$ Today, Africa's dream for a strong, independent and effective court that would assist it to secure enduring peace through the application of international justice to various conflict or post-conflict situations appears, at best, to be facing major challenges. At worst, the dream seems to be turning into a nightmare as AU leaders agonize over the "misuse of indictments against African leaders." 72

As the above quotations from AU Commission Chair Jean Ping and Rwandan President Paul Kagame demonstrate, some in Africa - especially national authorities whose roles are critical for the Court's success - are now beginning to question what they perceive as the blunt and one-sided application of the international criminal law instrument to indict only weak individuals from generally poor African states. ${ }^{73}$ Some of the opposition appears to stem from a conflation of the doctrine of universal jurisdiction with ICC

\footnotetext{
GR) Statement of the UN Secretary-General Kofi Annan at the ceremony held at Campidoglio celebrating the Adoption of the Stature of the International Criminal Courr, 18 May 1998.

(4)) Press Statement by UN Secretary-General Kofi Annan, 11 April 2002.

70) M. Mamdani, 'Darfur, ICC and the New Humanitarian Order: How the ICC's "responsibility to protect" is being turned into an assertion of neo-colonial domination', Pambazuka News 396 (English edn.), online at: <http://www.pambazuka.org> (visited 15 May 2009).

71) Mamdani, supra note 70.

72) AU Peace and Security Council Decision (PSC/MIN/Comm (CXLII)), 21 July 2008, para. 3.

${ }^{73)}$ As reporred in the Daily Nation, supra note 2.
} 
jurisdiction. ${ }^{74}$ Unfortunately, existing sensitivities have now been heightened to the point that President Kagame has gone so far as to suggest that the Court is a "fraudulent institution" reminiscent of "colonialism" and "imperialism" that is seeking to undermine and to control Africa. ${ }^{75}$ His position is echoed by others, such as President Thomas Yayi of Benin, who lamented the "harassment" of African leaders and concluded that " $[\mathrm{w}] \mathrm{e}$ have the feeling that this court is chasing Africa. ${ }^{76}$ On these views, the current trajectory of ICC indictment practice, limited as it is to investigations of African situations and African nationals, is mere manifestation of the efforts to transform itself beyond paper tigerdom into a legitimate and functional court of law. In other words, while exaggerated and largely unsupported by the facts, the growing perception is that Africans have become the sacrificial lambs in the ICC's struggle for global legitimation. ${ }^{77}$

There have been various criticisms of the Court in each of the four situations under its current scrutiny. However, Sudan has arguably been the most challenging for the ICC. Since the Security Council referral, the Prosecutor has successfully issued three arrest warrants arising from the Darfur investigations though there seems to be little or no prospect for their execution, at least, at this stage. ${ }^{78}$ The most recent of these was that of incumbent Sudanese President Omar Hassan $\mathrm{Al}$ Bashir. ${ }^{79}$ The latter has proven to be highly controversial within legal and political circles, in Africa and elsewhere.

\footnotetext{
74) The use of universal jurisdiction by certain European courts to indict African leaders, especially in Rwanda, started the general trend of opposition to the ICC among various states on the continent. This article does not discuss that important issue for space reasons.

75) See AFP, 'Rwanda's Kagame says ICC Targeting Poor, African Countries,' 31 July 2008.

76) Reuters, 'Benin leader warns ICC against "harassing" Africans', 27 September 2008, online at: <http://www.sudan.net/news/posted/16262.html> (visited 15 May 2009).

77) As will be seen through the discussion in this article, instead of being a foreign imposition, the ICC was actually invited to investigate three of the four African situations by Uganda, the CAR and the DRC. Only the Sudan investigation was imposed by the Security Council. Moreover, it is noreworthy that other African countries, such as the Ivory Coast, a non-party, was reportedly lobbying for the referral of its own situation to the ICC. It even lodged a declaration accepting ICC jurisdiction. See ICC Office of the Prosecutor, 'Communications Received by the Office of the Prosecutor of the ICC', 16 July 2003.

78) The ICC Prosecutor applied for arrests warrants for Ahmad Muhammad Harun and Ali Muhammad Abd-Al-Rahman (aka Ali Kushayb) in May 2007. In addition, the first summons to appear to ever be issued by the Court was made public in May 2009 in respect of Bahr Idriss Abu Garda, an alleged rebel leader in Darfur, who is scheduled to appear for confirmation hearings on three charges of war crimes against on 12 October 2009.

79) ICC Office of the Prosecutor, Press Release, 'ICC issues a warrant of arrest for Omar Al Bashir, President of Sudan', 4 March 2009; Situation in Darfur, Sudan (ICC-02/05-157) 'Public Redacted Version of Prosecutor's Application under Article 58 filed on 28 July 2008', Pre-Trial Chamber, 12 September 2008; Prosecutor v. Omar Al Bashir (ICC-02/05-157), 'Decision on the Prosecution's Application for a Warrant of Arrest against Omar Hassan Ahmad Al Bashir', Pre-Trial Chamber I, 4 March 2009 and 'Warrant of Arrest for Omar Hassan Ahmad Al Bashir', Pre-Trial Chamber I, 4 March 2009.
} 
Among the more contentious issues, even before the Bashir warrant was approved by the Pre-Trial Chamber, lawyers debated the accuracy of the Prosecutor's characterization of his alleged criminal conduct in Darfur as genocide and whether, or not, the President's immunities would evaporate if the arrest warrant is issued. ${ }^{80}$ Others considered whether an indictment unlikely to be executed in the short-term is pragmatic prosecutorial strategy in the longterm, and even the propriety of a Security Council deferral - as requested by African leaders within the AU framework. ${ }^{81}$ For their part, previous international prosecutors have rallied to publicly support the seemingly embattled MorenoOcampo. ${ }^{82}$

Even more significant to the future of the ICC as a young institution was the political reaction within regional organizations. In particular, following the Prosecutor's application for an arrest warrant for President Bashir, the PSC of the $\mathrm{AU}$, the primary decision-making organ for conflict resolution in Africa, immediately called on the UN Security Council to deploy Article 16 of the Rome Statute to "defer the process initiated by the ICC." ${ }^{83}$ In a number of strongly worded decisions, the AU observed that while it endorses criminal accountability

80) The UN Darfur Commission, chaired by the first ICTY President Antonio Cassese, concluded that the crimes in Darfur did not reveal the specific intent to commit genocide. This immediately spawned a debate. After the Prosecutor's public application for an arrest warrant, commentators questioned whether Bashir's alleged crimes amounted to genocide. See, e.g., A.T. Cayley, 'The Prosecutor's Strategy in Seeking the Arrest of Sudanese President Al Bashir on Charges of Genocide', 6 Journal of International Criminal Justice (2008) 829-840 and $A$. de Waal, 'Darfur, the Court and Khartoum: The Politics of State Non-Cooperation', in N. Waddell and P. Clark (eds.), Courting Conflict? Justice, Peace and the ICC in Africa (London: The Royal Africa Society, 2008). In its decision approving the arrest warrant, the ICC Pre-Trial Chamber found that the information supplied by the ICC Prosecutor did not show reasonable grounds to believe that the Sudanese government acted with specific intent to destroy, in whole on in part, the Fur, Masalit and Zaghawa groups. Charges for genocide were therefore not included for the arrest warrant. Nonetheless, the Chamber left a window open for an amendment or modification in light of any new information submitted subsequently under Art. 58(6) ICCSt. See Decision on the Prosecution's Application for a Bashir Arrest Warrant, supra note 79, at paras. 206-208.

81) C. Gosnell, 'The Request for an Arrest Warrant in Al Bashir', 6 Journal of International Criminal Justice (2008) 841-851 and A. Ciampi "The Proceedings Against President Al Bashir and the Prospects of their Suspension Under Article 16 ICC Statute', 6 Journal of International Criminal Justice (2008) 885-897.

42) For example, see $R$. Goldstone, 'Carching A War Criminal in the Act', The New York Times, 15 July 2008 and L. Arbour, 'Justice v. Politics', International Herald Tribune, 16 September 2008.

*3) AU Peace and Security Council Decision (PSC/MIN/Comm (CXLII)), 21 July 2008, paras. 3, 5, 9, 11(i); AU Assembly Decision on the Application by the International Criminal Court Prosecutor for the Indictment of the President of the Republic of the Sudan (Dec. 221 (XII), 3 February 2009, paras. 2, 3 and Peace and Security Council Decision (PSC/PR/Comm (CLXXV)), 5 March 2009, paras. 4-6. See also AU Press Statement, "The Chairperson of the Commission Expresses Deep Concern at the Decision of the Pre-Trial Chamber of the International Criminal Court on Darfur', 4 March 2009. 
for gross human rights violations, given the "delicate nature" of the processes currently underway in the Sudan, the search for justice should be pursued in a way that complements, rather than impedes, efforts to secure a lasting peace in the country. It also noted that ICC jurisdiction is based on complementarity and underscored that a prosecution in the current climate "may not be in the interest of the victims and justice" because it could lead to greater destabilization in Sudan and the region. ${ }^{84}$

While it has been suggested that there is in fact no peace process in Darfur, the AU apparently sees the ICC on a collision course with its own peacemaking efforts. ${ }^{85}$ Tanzanian President Jakaya M. Kikwete, speaking for the continent, publicly reiterated that "Justice has to be done. Just must be seen to be done. What the AU is simply saying is that what is critical, what is the priority, is peace." 86 The AU has therefore begun to lobby the support of other regional bodies, including the League of Arab States, the Organization of Islamic Conference and the Non Aligned Movement, ostensibly to rein in the ICC. Likely because of Sudanese backroom lobbying, all those organizations had for their own reasons already, or have since, publicly joined the AU chorus singing down the wisdom of indicting President Bashir at this time. ${ }^{87}$ This opposition will likely continue in the near future given the recent assumption of the AU chairperson position by erstwhile Sudanese ally and self-proclaimed anti-colonialist, President Muammar Gaddafi of Libya.

\section{Accountability for International Crimes and the Logic of Mutual Gain and Mutual Vulnerability}

Accountability for international crimes is not a matter of concern only to the UN or the international community. Indeed, the prosecution of serious international crimes is of concern to all African states - at least, if we take their concrete actions on the responsibility to protect within the AU setting at face value. At the level of

\footnotetext{
84) The AU has been seeking a peaceful resolution to the Darfur crisis, and as part of this, deployed the first hybrid peacekeeping force between the UN and a regional organization to Sudan in July 2007 pursuant to SC Res. 1769, 31 July 2007.

${ }^{85)}$ Goldstone, supra note 82 (arguing, inter alia, that '[s]o far, there has been no Darfur peace process to speak of.')

${ }^{86)}$ Reuters, 'AU chairman backs Sudan's Bashir over court', 8 September 2008, online at: <http:// www.reuters.com/article/latestCrisis/idUSL8101824> (visited 15 May 2009).

${ }^{87)}$ For e.g., see 'OIC Secretary General [Ekmeleddin Ihsanoglu] strongly rejects the ICC indictment against President of the Sudan', 4 March 2009 (expressing his disappointment over the Bashir indictment; warning that it could lead to 'dangerous ramifications' ; rejecting the 'kind of selectivity and double standards applied by the international community' in addressing international crimes and appealing to the Security Council to 'suspend the move by the ICC in the interest of the ongoing peace efforts in the Sudan') and 'Statement of the Extra-ordinary session of the Ministerial Council of the League of Arab States to examine the Developments in Darfur Region', 8 August 2008.
} 
individual countries, we also see indications of that desire. Perhaps the best examples of this commitment to address impunity are the SCSL and the ICTR. Though funded by the international community, the formal requests for their establishment originated from Freetown and Kigali respectively.

Senegalese authorities have also been at the forefront of controversial efforts, which recently reached the International Court of Justice (ICJ), to exercise universal jurisdiction over crimes allegedly committed in Chad by former President Hissène Habré. ${ }^{88}$ No less important have been efforts by Ethiopia’s high courts to try former military leaders, namely, Mengistu Haile Mariam. Other African countries, for example, Burundi have long campaigned for international support for a special tribunal. Similarly, in Liberia, civil society organizations are increasingly agitating for the prosecution of international crimes to supplement the work of the local truth commission. The lack of political support from the government for such a tribunal makes it highly unlikely. ${ }^{89}$ Nonetheless, the trend towards ensuring individual accountability in Africa has continued with the most recent proposal being for an internationalized Special Tribunal for Kenya to prosecute those bearing greatest responsibility for post election violence following disputed multi-party elections. This is in addition to the increasing practice of prosecuting serious crimes in various types of African national courts. ${ }^{90}$

From the international community point of view, enhancing accountability for serious international crimes is the core justification for the permanent Court. In this regard, we may recall the statement of Judge Phillipe Kirsch, then President of the ICC, in his speech to the AU on 17 June 2006 that "without Africa the ICC would not exist as it does today; and because of the relationship between the Court and African States, cooperation with the $[\mathrm{AU}]$ is particularly important to

*8) Report of the Committee of Eminent African Jurists on the Case of Hissene Habre, (Addis Ababa, AU: 2006) online ar: <http://www.hrw.org/justice/habre/CEJA_Repor0506.pdfs (visited 15 May 2009); AU Assembly Decision (Dec.127(VII)), 2 July 2006 (mandating Senegal 'to prosecute and ensure that Hissène Habré is tried, on behalf of Africa, by a competent Senegalese court with guarantees for fair trial') and Dec. 240(XII), 3 February 2009 (urging African and other states to contribure funds to the budget established for the case to enable its prosecution). See also ICJ, Press Release No. 2009/13, 'Belgium institutes proceedings against Senegal and requests the Court to indicate provisional measures', 19 February 2009, online at: <http://www.icj-cij.org/docket/files/ 144/15052.pdf>; Press Release No. 2009/14, 'Proceedings institured by the Kingdom of Belgium against the Republic of Senegal Request for the indication of provisional measures', 12 March 2009, online at: <http://www.icj-cij.org/docket/files/144/15092.pdf (visited 15 May 2009).

k9) C. Jalloh and A. Marong, 'Ending Impunity: The Case for War Crimes Trials in Liberia' 2 African Journal of Legal Studies (2005) 53-79 (arguing that the polirical will did not exist for an internationally supported special court for Liberia; suggesting instead that the SCSL be mandated to prosecute international crimes commitred there).

90) J. Rikhof, 'Fewer Places to Hide? The Impact of Domestic War Crimes Prosecutions on International Impunity', I Criminal Law Forum (2009) 1-51 (reviewing domestic prosecutions in, among others, Africa). 
the Court."91 The Prosecutor, Registrar and some judges have all acknowledged the importance of this evolving relationship. ${ }^{92}$

Essentially, both Africa and the ICC have much to gain from each other. This, in my view, entails two distinct but mutually reinforcing aspects embedded in the Rome Statute and the AU's Constitutive Act as well as the Peace and Security Protocol. In the first place, all three instruments conceive of the prevention of international crimes as a fundamental objective. This is evident from even a cursory reading of their respective preambles. Secondly, where the Court's and Africa's efforts fail to yield prevention outcomes and certain international offences are in fact committed, the substantive provisions provide for the punishment of the key perpetrators of such crimes. The two regimes are therefore conjoined by the shared belief that prosecution of international offences would likely deter others from committing such crimes in the future. Against this backdrop of their respective objectives and mandates, it seems rather obvious that collaboration would offer Africa and the ICC mutual gain and that there would be lost opportunities and a "mutual vulnerability" should they fail to do so.

\subsection{A "Win-Win" for the International Criminal Court}

While perhaps evident to international lawyers, this point nevertheless needs to be made and emphasized given the apparent unpopularity of the Court within certain African circles. Cooperation between African countries and the ICC to battle impunity offers a "win-win" prospect for a new court struggling to find its feet and place in the world, and on the other hand, is a blessing for a continent in search of a sustainable peace after centuries of violence and turmoil. With its current four investigations in Africa, the Court will gain significant benefits if it successfully prosecutes its maiden cases in fair trials meeting the highest standards of international justice. In this way it would prove itself as a functional and effective court of law.

The importance of this to the ICC cannot be overemphasized. This is particularly so considering that, as one commentator has noted, it was established over 6 years ago, has spent over $\$ 600$ million dollars, and only has 4 accused in its custody while 7 (now 8) of its 12 (now 13) arrest warrants remain outstanding. ${ }^{93}$ After legendary difficulties over disclosure, the sole Lubanga trial finally got

\footnotetext{
91) As quoted by Kambudzi, supra note 61 , at 43 .

92) See, e.g., Judge N. Pillay, 'The rise of the International Criminal Court: complementarity and domestic prosecution of international crimes' in $M$. du Plessis and $A$. Louw (eds.), The Investigation and Prosecution of 'core international crimes' and the role of the International Criminal Court in Africa (Pretoria: Institute for Security Studies, 2007) pp. 13-22, at 13-14.

93) Ciampi, supra note 81 , at 892 .
} 
underway in early $2009 .{ }^{94}$ In this context, the Court is now at a crucial stage of its existence where it strongly needs to achieve and to show tangible judicial results. ${ }^{95}$ The benefits of such success for its work and reputation would be immense.

Without attempting to be exhaustive, to begin with, fair and independent trials will boost state confidence in the ICC as a new institution and perhaps even generate more referrals and ratifications from other countries in Africa and elsewhere. This would help to advance the Prosecutor's apparent preference for selfreferrals in selecting situations. Crucially, if it shows independence and effectiveness, the Court will likely reassure the skeptical but powerful holdout states, such as the U.S., China and India, who between themselves constitute well over half of the world population, that it can discharge its mandate effectively and thereby merits their support. This will help it to not only achieve universal reach, but to also transform or co-opt superpower opposition to its work to its advantage. As the world's most powerful state seeks to climb back to a position of moral leadership of the world, that country will have much to offer the ICC whenever it becomes a State Party. ${ }^{96}$ These include American technical, financial, diplomatic and other support - similar to the kind it quietly offers the ad hoc tribunals.

Second, as various recitals of the Rome Statute preamble confirm, the ICC was intended to address atrocities that "deeply shock the conscience of humanity" based on the recognition "that such grave crimes threaten the peace, security and well-being of the world." Indeed states resolved that the "most serious crimes of concern to the international community as a whole" must not go unpunished. They also affirmed that responsibility for prosecution of such crimes requires that measures be taken at the national level and through international cooperation. Thus, crucially and unlike the ad hoc tribunals, the Court only possesses secondary jurisdiction vis-à-vis the primary jurisdiction of states. This is entrenched through the complementarity principle. The underlying logic of that principle is that the permanent court must supplement the work of national jurisdictions; hence, it can only exercise jurisdiction when states prove to be unwilling or unable to prosecute. In this way, complementarity enables the ICC to give effect to states' collective determination "to put an end to impunity" for the perpetrators of international crimes and "thus to contribute to the prevention of such crimes." "?

\footnotetext{
94) H. Stuart, 'The ICC in Trouble', 6 Journal of International Criminal Justice (2008) (discussing the stay of proceedings in the Lubanga case and the disclosure debacle).

95) Ciampi, supra note 81 , at 892 .

96) D. Scheffer et al., 'The End of Exceptionalism in War Crimes: The International Criminal Court and America's Credibility in the World', Harvard International Review, 21 November 2007.

97) Emphasis added.
} 
As Prosecutor Moreno-Ocampo has rightly observed, the consequence of complementarity is that:

the number of cases that reach the Court should not be a measure of its efficiency. On the contrary, the absence of trials before this Court, as a consequence of the regular functioning of national institutions, would be a major success."

Hence, from the Court's prism, if African countries conduct fair and effective national prosecutions, it offers a key advantage in that it will allow it to in turn focus on the high ranking accused deemed to be "most responsible" or "bearing greatest responsibility" for international crimes in other parts of the world. Under this model, the ICC and African states could carve an informal division of labor whereby the affected countries undertake prosecution of lower and middle ranking suspects while leaving ranking perpetrators, the ostensible "big fish", to international investigation and prosecution. This is the mandate and also stated goal of the Prosecutor who has affirmed that he will only pursue those holding leadership positions but warned about an "impunity gap" if national authorities fail to deploy other means to bring lower tier persons to justice. ${ }^{99}$ In practice, this consensual division of labor appears to have been the informal understanding reached between him and DRC authorities. ${ }^{100}$ The more difficult question is whether this can be done in a manner that does not effectively confer immunity from prosecution to the government, as opposed, to the rebel or opposition side. $^{101}$

Third, it will obviously be less costly for the Court if African countries can prosecute their own genocidaires and war criminals. This is particularly important considering the substantial funds required to hold trials thousands of miles away from the crime base in a faraway European city (The Hague). This issue is more important than might first appear, even for the relatively rich ICC. One example from the experience of the SCSL with the trial of former Liberian President Charles Taylor will suffice to illustrate the point.

Following his arrest, a highly controversial decision was made to change the venue of the trial from Sierra Leone to the Netherlands for security reasons. ${ }^{102}$ The Prosecution case formally commenced on 4 June 2007, but because of serious

98) ICC Office of the Prosecutor, 'Paper on some policy issues before the Office of the Prosecutor', Seprember 2003, at 4.

99) Paper on some policy issues before the Office of the Prosecutor, supra note 98, at 3 .

100) ICC Office of the Prosecutor, 'Statement of the Prosecutor Luis Moreno-Ocampo to Diplomatic Corps', 12 February 2004, at 4.

101) Schabas, 'Prosecutorial Discretion v. Judicial Activism', supra note 21, at 752.

102) Jalloh, 'The Law and Politics of the Charles Taylor Case', supra note 35 and C.C. Jalloh, 'Special Court for Sierra Leone Dismisses Taylor Motion for Change of Venue', 10 American Society of International Law Insights 15 (15 June 2006), online at: <http://www.asil.org/insights060615.cfm> (visited 15 May 2009). 
difficulties relating to provision of adequate counsel for the Accused, only had witnesses testifying as of 7 January 2008. After calling 91 witnesses, the Prosecution closed its case on 30 January 2009. Around the same time, media reports indicated that the tribunal's donations have dried up and that Taylor may be released due to lack of funds - even before entering his defence. ${ }^{103}$ Admittedly, the financial woes dogging the SCSL are not new. The UN, which has in the past stepped in to address anticipated donor shortfalls, may also provide a subvention grant. Among the reasons are that it cannot afford to lose credibility by allowing a closure of the tribunal under such circumstances.

Be that as it may, the decision to try Taylor in The Hague, The Netherlands, rather than in Freetown, Sierra Leone, exponentially multiplied the costs of the trial - as foreshadowed by this commentator. ${ }^{104}$ For example, substantial additional funds had to be generated for the already cash strapped court to establish and maintain a miniature version of the SCSL in The Hague, to hire and pay salaries of approximately 100 staff members, to fly in and sustain witnesses, mostly from West Africa, in a rented safe house, to lease and retrofit a courtroom from the ICC and to bear the costs of hosting Mr. Taylor at the Scheveningen Detention Facility. ${ }^{105}$

Perhaps more importantly, aside from saving funds that could then be diverted to compensate victims of international crimes, in situ prosecutions will give Africans the opportunity to witness their tormentors being brought to justice. Based on the experience of the first generation UN tribunals, this is now widely acknowledged to be an important goal for international criminal justice. By exposing the truth about the atrocities committed to locals, it could assist victims in their healing and may contribute to reconciliation in the long-term. From an ICC perspective, this may resolve growing complaints about the extent of national participation in its processes because of a geographic divorce between the accused, the crime and victim base and the formal seat of the court and trials in The Hague.

Finally, encouraging national prosecution would be a pragmatic decision for the Court that would enhance efficiency because it simply cannot address every meritorious situation. Besides, states are usually the best placed to address

\footnotetext{
1113) K. Manson, 'Lack of funds may mean Liberias Taylor freed - prosecutor' <http://www.reurers .com/article/latestCrisis/idUSLO563309> (visited 15 May 2009).

1114) Jalloh, 'The Contribution of the Special Court for Sierra Leone', supra note 64, at 204 (identifying funding as the first of two big challenges that would confront the SCSL when it relocated the Taylor trial to The Hague).

105) The agreement between the SCSL and the ICC provides for the former to pay to the latter, in advance, for all services, facilities and support provided to it. These included courtroom and detention services. See Arts. 3,5 and 18 of the Memorandum of Understanding Regarding Administrative Arrangements between the International Criminal Court and the Special Court for Sierra Leone in C.C. Jalloh (ed.), Consolidated Legal Texts for the Special Court for Sierra Leone (Leiden and Boston: Martinus Nijhoff Publishers, 2007) 125-136, at 127-128, 135.
} 
international crimes from a criminal process point of view. Indeed, while perhaps cynical in light of the continent's strong role in the development of many of the international criminal justice mechanisms discussed above, some observers have argued that the Court is now giving Africa the courage necessary to face up to its dark past. It is apparently also now beginning to get past the sense of victimhood that long justified an aggressive anti-colonial agenda. In the result, it has been suggested, a ripple effect of the ICC that is already been felt is to show that "black on black" violence is no more acceptable morally and legally than "white on black violence". ${ }^{106}$

\subsection{A "Win-Win" for Africa}

With a strong, impartial and effective ICC, Africa is likely to be an even bigger beneficiary of a solid relationship with it. First, at the regional level, African governments can better achieve the broader good governance and rule of law objectives outlined in the AU's constitutive instruments, especially the ambitious and proactive conflict prevention and management system anticipated by the Peace and Security Protocol. This will enhance the ability of the region to continue blazing the trail in implementing the responsibility to protect.

Second, the Court can assist African governments to build capacity in the prosecution of serious international crimes within their domestic tribunals. In fact, the Prosecutor has indicated that he will enter into cooperation arrangements with national counterparts to assist in capacity-building to fulfill a key objective of the Rome Statute, that is, to ensure local prosecutions of international crimes based on the complementarity principle. ${ }^{107}$ To the extent that this policy is backed up with action, the spin off effects could be to strengthen domestic criminal legislation in African countries and to perhaps enhance the ability of national justice systems to deliver more credible justice. For example, Uganda's current Director of Public Prosecutions has argued that in certain areas like witness protection, poorer countries are least able to undertake extensive programs that would give the protections required to convince critical witnesses, who often fear reprisals, to testify. ${ }^{108}$ He suggested that the ICC could draw on the

\footnotetext{
106) K. Chitiyo and L. Devlin, 'The International Criminal Court and Africa', 28 The Royal United Services Institute Newsbrief 8 (2008) 67-70, at 69.

107) Paper on some policy issues before the Office of the Prosecutor, supra note 98, at 5 .

108) $R$. Buteera, 'Best practices and challenges encountered when prosecuting and investigating international crimes in Uganda', in $M$. du Plessis and A. Louw (eds.), The Investigation and Prosecution of 'core international crimes' and the role of the International Criminal Court in Africa (Pretoria: Institute for Security Studies, 2007) pp. 57-67, at 65. Another example of the challenges faced by African countries in ensuring adequate witness protection and the impact of that on potential witnesses' ability to testify recently arose in respect of applications for the transfer of genocide cases to Rwanda for trial. See, e.g., Prosecutor v. Gaspard Kanyurikiga (ICTR-2002-78-R11bis), Trial Chamber, 'Decision on Prosecutor's Request for Referral to the Republic of Rwanda', 6 June 2008,
} 
experience and expertise of the ad hoc international courts to provide technical assistance on witness protection to national judicial systems. ${ }^{109}$

Third, and perhaps more fundamentally from a concerned African government perspective, an enhanced capacity to claim their first right to prosecute the international crimes within the jurisdiction of the Court may be the best weapon in their arsenal to counter any attempts to encroach on their state sovereignty. In fact, to counter the Prosecutor's alleged overemphasis on situations in the continent, African leaders are better off looking to the future to start building the necessary criminal justice systems that would enable them to fulfill their treaty obligations under the Rome Statute. In many ways, theirs and the ICC's objective of encouraging action at the national level to mete out accountability would be better achieved through such concrete steps than making dramatic allegations in the media.

Furthermore, assuming prosecutions have some deterrent effects, strong legal systems may ultimately not only help prevent or minimize the phenomenon of international crimes within African countries, they would serve to deprive the Court of jurisdiction. Of course, this will help ensure that their willingness, and more importantly ability, to punish such crimes is beyond reproach in an Article 17 of the Rome Statute "unwilling or unable genuinely" assessment. Moreover, while ICC-style criminal justice has great promise, a "one size fits all" approach to counter impunity is unlikely to work in all situations given the variety of challenges confronting African and other nations experiencing conflict. This is compounded by the reality that some governments may legitimately need policy room to fashion solutions to ensure accountability in line with local realities, preferences, cultures and traditional justice mechanisms.

But it is noteworthy that in as much as African governments have been quick to try and convict the Court for paying too much attention to their problems (despite having invited it to do so in three out of four situations through "selfreferrals"), civil society on the continent has not been as vocal in condemning the permanent court. If anything, it tends to be supportive of the ICC. ${ }^{10}$ Indeed, some have applauded the Court for forcing Africa to confront its governance and

paras. 63-81, 104; affirmed by the Appeals Chamber in 'Decision on the Prosecution's Appeal Against Decision on Referral under Rule 11bis', 30 October 2008; Prosecutor $v$. Ildephonse Hategekimana (ICTR-00-55-R1 1 bis), Trial Chamber, 'Decision on Prosecutor's Request for Referral of the Case of Ildephonse Hategekimana to the Republic of Rwanda,' 19 June 2008, paras. 61-71; affirmed by the Appeals Chamber in 'Decision on the Prosecution's Appeal against Decision on Referral under Rule 11 bis', 4 December 2008.

(10)) Buteera, supra note 108 , at 65.

111) For instance, see Darfur Consortium, Press Release, 'Bashir warrant: a major step towards justice for victims in Darfur', 4 March 2009, online at: <http://www.darfurconsortium.org> (visited 15 May 2009). The consortium is a coalition of more than 50-Africa based and Africa-focused NGOs dedicated to a 'sustainable solution' to the human rights crisis in Darfur. 
justice demons and for seeking to end the so-called "tradition of big man" impunity"." Given the current democracy deficit on the continent, the gap between the concerns expressed by African politicians and local populations is hardly surprising. Indeed, it may reflect the sad reality that the selfish interests of many undemocratic Third World governments, including quite a few in Africa, are not necessarily coextensive with or in sync with those of their citizens. Certainly, in some countries on the continent, the populations clamor for change while their leaders do everything to cling to power. One might cite the example of Zimbabwe, whose President Robert Mugabe, seems intent on doing whatever is necessary, including the alleged commission of torture and disappearances, so that he can continue to rule. ${ }^{112}$

Fourth, from the perspective of conflict torn African countries, the benefits of a strong and effective ICC may extend well beyond trials of those most responsible for genocide, crimes against humanity and war crimes. It might ultimately be addressing the substantive crime of aggression. The Court will not try individuals for that crime until it is defined as per Articles 121 (addressing amendments) and 123 (review) of the Rome Statute. Yet, progress reports on such a definition suggest that one might eventually be agreed by states - even if much later than within the relatively short time period initially envisaged. Once that happens, it could offer a significant benefit in the fight against the scourge of conflict - a matter that we have already seen is of grave concern to Africa.

It seems true that in the conflicts on the continent nowadays, aggressors tend to be other African states, acting directly or through proxy rebel groups, instead of others further afield - as was the case historically. A good example of this is the ongoing conflicts in the Great Lakes region in which a number of states in the East and Central Africa sub-regions have been implicated. A similar situation arose in West Africa in relation to the wars in Liberia and Sierra Leone, in the Horn of Africa as well as in southern Africa. These examples suggest that the value the continent should attach to the idea of subjecting the crime of aggression to prosecution should be high. If this is so, it may well be that the biggest benefit that the Rome Statute confers on Africa is yet to come - particularly considering the number of ongoing conflicts on the continent at any given time.

Viewed in this context, this may not be the right time for African states to opt out of the international criminal justice system hinged on the ICC. Indeed, they could channel their obvious concerns with current prosecutorial practice

\footnotetext{
i11) Chitiyo and Devlin, supra note 106, at 69.

112) Among others, there have been many allegations of torture, disappearances and killings of members of the political opposition, civil society activists and student leaders by government security forces with impunity. See, e.g., United States Department of State, 2008 Country Reports on Human Rights Practices, Zimbabwe, 25 February 2009, online at: < http://www.state.gov/g/drl/rls/ hrrpt/2008/af/1 19032.htm> (visited 15 May 2009).
} 
through filings of legal briefs before the judges of the Court or within the more political framework of the Assembly of States Parties. In other words, it is perhaps in the numerous wars within Africa that individual countries may benefit the most from the ICC by leveraging its power to limit, if not minimize, the number of likely wars on their territories. Of course, the important assumption being that a definition of the crime will lead to its prosecution which, in turn, would help deter at least some leaders in the future from sponsoring aggression against other states.

This will obviously not only be to Africa's advantage. For the international community as well, a definition of the crime of aggression, which is taking place within the framework of an ICC working group in which African nations are represented, will help develop the jus ad bellum, the law on the use of force, thereby bringing it closer than ever before to achieving the objective in the first paragraph of the UN Charter preamble to save succeeding generations of humanity from the scourge of war. That this is an issue that preoccupies many less powerful nations is confirmed by the fact that it is the nonaligned countries, perhaps the largest issue bloc in the world, which pushed for the inclusion of aggression in the Rome Statute. ${ }^{113}$ While because of initial definitional disagreements the crime is not yet prosecutable, it is to be hoped that the current divergence of views, including regarding the role of the Security Council in triggering prosecutions, will ultimately be resolved in a manner that reflects Africa's interest. ${ }^{114}$ Given the series of internecine conflicts on the continent, success with a definition will likely give even more impetus to the remaining African signatories to file the outstanding ratifications to the Rome Statute. It may also encourage other nations harbouring similar concerns, on the continent but also elsewhere in the developing world, to accede to the treaty.

Fifth, the Rome Statute bridged an important regulatory gap in international humanitarian law whereby war crimes committed in "international" armed conflicts were privileged over those of a "non-international" character. In international conflicts, states had a duty to prosecute or extradite those who violate the "grave breaches" provisions of the four 1949 Geneva Conventions. Whereas in internal conflicts, states had no corresponding obligation in respect of the conduct that common Article 3 sought to regulate. Indeed, the latter provision did not establish criminal liability for such conduct. An attempt was made to expand its scope of application in Additional Protocol II in 1977; however, the changes that states ultimately adopted were limited. ${ }^{115}$

\footnotetext{
113) Schabas, An Introduction to the ICC, supra note 30 , at 31.

114) UN Department of Public Information, 'Press Conference on Special Working Group on Crime of Aggression', 13 February 2009.

115) Schabas, An Introduction to the ICC, supra note 30, at 64.
} 
Though Article 8 of the Rome Statute formally maintains this distinction between international and non-international armed conflicts, it nevertheless criminalizes in a single provision many of the more reprehensible acts committed in both types of conflict. In effect, through this codification of the relevant war crimes in a single place, it effectively renders the distinction nugatory in the legal regime applicable before the ICC - the key site for future international prosecutions should states show a lack of fortitude or means to act. In addition, because the provision captures the collective views of many states on the matter, it also suggests that this distinction has become less germane to criminalization of certain reprehensible acts under customary international humanitarian law as well. ${ }^{116}$

This may benefit all ICC States Parties since it perhaps heralds the death of an archaic legal distinction which effectively imposed individual criminal responsibility for serious international humanitarian law violations based on the nature of the underlying conflict, rather than the gravity of the underlying act. The travaux prepratoires reveals that African delegations urged other states to eradicate this distinction during the Rome negotiations. This position is exemplified by the statement towards that end made by the representative of the 15 countries of the Southern Africa Development Community. ${ }^{17}$ It appears that those countries were alive to the issue and the benefits of such a move for Africa since, as we saw earlier, it continues to grapple with more conflicts than any other region in the world. In this vein, it is interesting to note in passing that humanitarian law is said to have established this division between types of conflicts partly because of colonial power preoccupations to exempt from legal regulation the serious violence used to suppress anti-colonialist resistance. ${ }^{118}$ Indeed, to some, it is no accident that despite the many atrocities committed against other peoples, international law failed to show any meaningful concern about prosecuting gross human rights violations within a state until Europeans experienced the tragedy of the Holocaust during the twentieth century. ${ }^{119}$

116) Prosecutor v. Dusko Tadic (ICTY-94-1-AR-72), Appeals Chamber, 'Decision on the Defence Motion for Interlocutory Appeal on Jurisdiction', 2 October 1995, paras. 86-137 at 134 (concluding, inter alia, that 'customary international humanitarian law imposes criminal liability for serious violations of common Article 3 '). The authoritative ICRC commentary on customary international humanitarian law cites two other treaties and contemporary state and international organization practice to conclude that this is now a norm of customary international law. See J-M Henckaerts and L. Doswald-Beck (eds.), Customary International Humanitarian Law (Cambridge: CUP, 2005) at Rules 151, 551-554.

117) H.E. A. M. Omar, Minister for Justice (Head of South Africa's Delegation to the Rome Negotiations) Statement at 2nd Plenary Meeting, 15 June 1998. See Official Records of the United Nations Diplomatic Conference of Plenipotentiaries on the Establishment of an International Criminal Court, UN doc. A/CONF.183/13 (Vol. II) 104, 65 at para. 15.

118) A. Anghie and B.S. Chimni, 'Third World Approaches to International Law and Individual Responsibility in Conflicts', 2 Chinese Journal of International Law (2003) at 88.

119) Ibid., supra note 118 , at 88 . 
Sixth, the ICC's ability to prosecute international crimes may prove to be a useful tool for African countries engaged in conflict as it could assist them to end some of the long-running wars in the region. By "backstopping peace negotiations", ${ }^{120}$ for instance, that between Uganda and the Lord's Resistance Army (LRA), the Court may play a constructive role to restore peace in war ravaged societies. Indeed, close cooperation between the Prosecutor and the concerned governments may nudge otherwise recalcitrant parties towards agreement, especially in circumstances where a clear military victory by one of the parties to the conflict seems elusive. In this regard, the notion that criminal prosecutions were but a small part of the larger puzzle to secure or restore peace and stability seemed to be consistent with the early views of Moreno-Ocampo. ${ }^{121}$

Of course, the Prosecutor should never promise a party to a conflict that he will not prosecute. Nor should he align himself too closely to a particular government to compromise his independence and ability to prosecute their forces. Still, where arrest warrants have been issued against rebel leaders in places like Uganda, steps that are consistent with the broader goal of ending impunity could be taken. The range of measures will necessarily differ, depending on the situation, but could include listening to the views of the concerned communities and continuing to monitor the situation. He could then show flexibility in the use of his power - keeping in mind the realities on the ground and the likelihood, or not, of apprehending the suspects. Where merited, he could invoke the "interests of justice" to cease an investigation or to re-evaluate a prior decision to prosecute based on new facts or information. ${ }^{122}$

But the Court's current Prosecutor has rejected any such back-stopping function to peace deals. In respect of the Ugandan situation, for example, he stated that because he is not a "party" to any peace process, he would not comment on it or, for that matter, the content of any agreements. In other words, he would insist on the law taking its course. If one adopts a positivist reading of the Rome Statute, this position can hardly be faulted. At the same time, as difficult as it may be for diehard internationalists to accept, in certain situations, the best interests of the victims and justice may be to delay, stop or avoid prosecutions - at least imminently. ${ }^{123}$ Otherwise, victims may wonder what will happen if a strict insistence on applying the letter of the law leads to patently absurd results.

Ironically, the same Prosecutor had, in discussing Article 53 of the Rome Stature, noted that the "interests of justice" would require that the ICC play as complementary a role as possible in the pursuit of broader justice goals. ${ }^{124}$ Still,

\footnotetext{
1211) Kambudzi, supra note 43, at 37.

121) ICC Office of the Prosecutor, 'Starement by Luis Moreno-Ocampo to the Fourth Session of the Assembly of State Parties', 28 November - 3 December 2005 at 3.

122) Arts. 53(2)(c) and 53(4) ICCSt (Initiation of an investigation).

${ }^{123)}$ ICC Office of the Prosecutor, 'Policy Paper on the Interests of Justice', September 2004, at 8.

124) Ibid. at 8 .
} 
he has gone on to maintain that the interests of justice are not necessarily the same as the interests of peace, with the former falling within his domain and the latter within that of other institutions, specifically, the Security Council. This position is said to be problematic for seeking to define such a broad notion and, in any event, is not grounded in the drafting history of the Rome Statute. It may even constitute a form of unilateral and indirect amendment of the Court's founding instrument because it may have upset the balance carefully struck by states during the negotiations to build a measure of interpretative flexibility into the system. ${ }^{125}$ Whatever the case, if the Prosecutor turns a blind eye to the constraints faced by victims on the ground, he would likely undermine confidence and goodwill towards his ongoing work in the Africa region.

In spite of this, the propriety, manner and extent of the ICC's involvement in peace negotiations should be determined on a case-by-case basis. And in all cases, it must be carefully managed so as to avoid undue difficulty, including actual or perceived conflicts of interest, in pursing trials should negotiations fail and prosecutions ensue. In any event, in the Ugandan situation, the arrest warrants are now like the sword of Damocles hanging over the heads of alleged LRA leaders, in particular, Joseph Kony. The possibility that they can be enforced at anytime is said to have motivated negotiation of a peace agreement. So far, none has been finalized because of Kony's reported fears of being arrested. ${ }^{126}$ Yet, such action on the part of Moreno-Ocampo appear to be consonant with the complementarity principle and, assuming a comprehensive peace accord is signed and proves durable, would not be against the long-term interests of the Court. Indeed, if it were to play a constructive role to end the long and tragic conflict in northern Uganda, the ICC could justifiably claim credit that its work had deterred further hostilities and human rights atrocities in that nation. That some of the leaders of the victim communities have expressed a preference to explore alternative forms of accountability and reconciliation, instead of prosecution and retribution, would clearly strengthen his position. ${ }^{127}$

Related to this, the Court's work has raised concerns about the appropriate balance between the need for individual criminal accountability to send a strong signal against impunity and domestic amnesties where those become a necessary precondition for the conclusion of a peace accord. For instance, but for the inclusion of what later proved to be a controversial blanket amnesty provision in Article IX of the Lomé Peace Agreement, the Revolutionary United Front rebels would not have agreed to end the notoriously brutal war against the government

125) Schabas, 'Prosecutorial Discretion v. Judicial Activism', supra note 21, at 749.

126) See, e.g., J. Gettleman, 'UN Envoy Meets with Ugandan Rebel', The New York Times, 13 November 2006 (reporting that the thorniest issue for Kony was the arrest warrants issued by the ICC).

127) ICC Office of the Prosecutor, Press Release, 'Statements by ICC Chief Prosecutor and the visiting Delegation of Acholi leaders from northern Uganda', 18 March 2005. 
in Sierra Leone. ${ }^{128}$ Indeed, where used properly, amnesties may help contribute to the cessation of hostilities, reintegrate displaced civilians and former combatants into society, and promote post-conflict reconciliation.

In Uganda, a bill was enacted granting a broad amnesty to all combatants engaged in war since 26 February $1996 .{ }^{129}$ Certain classes of LRA members, who allegedly committed crimes, were expected to benefit from this law. The ICC Prosecutor has since clarified that he is only interested in those bearing greatest responsibility. This means that he will only pursue alleged leaders such as Kony and his cronies. A legal question that remains, however, is whether an amnesty granted under Ugandan law could serve as a bar to prosecution of international crimes.

Under international law, there seems to be an emerging norm suggesting that domestic amnesty laws do not bar international criminal tribunals from prosecuting international crimes. Pronouncements along these lines have been made by various courts and bodies. ${ }^{130}$ The trouble is how does one enforce such a norm, even assuming that it was universally agreed instead of contested? For the ICC, this will likely be a challenge considering that, under complementarity, it only has a right to a bite of the jurisdictional cherry if the state fails to bite. In other words, it is uncertain what the Court can practically do in a situation where a referring state - perhaps driven by domestic pressures for a political compromise - is prepared to offer an amnesty in return for peace to an individual alleged to have been involved in the perpetration of international offences. The hard reality is that even the ICC must rely on the goodwill and cooperation of national authorities to perform even its most basic functions. It follows that a recalcitrant state could put many practical obstacles to thwart its ability to investigate and prosecute cases under such circumstances.

Finally, Africa can and should use the Court to continue spotlighting its anti-impunity initiatives and agenda to advance the responsibility to protect. This is particularly important given the fleeting attention span of a Security Council

\footnotetext{
128) Sierra Leone Truth and Reconciliation Commission, Witness to Truth: Report of the Sierra Leone Truth and Reconciliation Commission, Vol. 1 (Freetown: TRC, 2004), Chapter I, at para. 17. See the full text of the provision and the peace accord in Jalloh (ed.), Consolidated Legal Texts for the Special Court for Sierra Leone, supra nore 105, 563-597 at 572.

129) Buteera, supra note 108, at 64.

131) See, e.g., Prosecutor v. Morris Kallon, Brima Bazzy Kamara (SCSL-2004-15-PT), Appeals Chamber, 'Decision on Challenge to Jurisdiction: Lomé Accord Amnesty', 13 March 2004 at para. 67 (concluding that 'a State cannor bring into oblivion and forgetfulness a crime, such as a crime under international law, which other States are entitled to keep alive and remember.'); Report of the Secretary-General on The Rule of Law and Transitional Justice in Conflict and Post-Conflict Situations, UN doc./S/2004/616 (2004) at para. 32 (stating that 'United Nations-endorsed peace agreements can never promise amnesties for genocide, war crimes, crimes against humanity or gross violations of human rights.') and Henckaerts and Doswald-Beck (eds.) Customary International Humanitarian Law, supra note 116, Rule 159 at 611-614 (citing state and Security Council practice in relation to amnesties; explaining the ICRC view that Additional Protocol II cannot be interpreted as allowing war criminals to escape prosecution).
} 
seemingly overwhelmed with global hot spots in a less then peaceful post-Cold War world. With an engaged ICC, the continent could more easily generate the necessary international interest and assistance in resolving its human security nightmares. As the tragic example of Rwanda's genocide showed in 1994, Africa cannot take for granted that security concerns within its own backyard are necessarily a top priority for the UN and the international community - even when those matters fall squarely within the contours of Article 39 of the UN Charter.

It may be recalled that African leaders decried the Security Council decision to downgrade, instead of increase, the mandate and capabilities of the UN Assistance Mission for Rwanda (UNAMIR) as the genocide, in which close to an estimated one million people were ultimately killed, was unfolding in that country between April and July 1994. Before the resolution reducing the size of UNAMIR was adopted by the Security Council, the OAU Secretary-General Salim Ahmed Salim warned that the international community would be turning its back on the people of that country and Africa at a time when the UN was rightly redoubling its efforts to protect human lives in other parts of the world. ${ }^{131}$ The then Tanzanian President Ali Hassan Mwinyi, the primary facilitator of the Rwandan peace process, presciently observed just days after the resolution downscaling UNAMIR was adopted that it was perhaps "one of the most unfortunate" decisions ever taken by the Security Council, which stood in "sharp contrast" to the level of UN engagement elsewhere. ${ }^{132}$ Given such a context, African leaders, who at once would complain if the international community did not pay attention to crises exercising the continent, will risk losing credibility if, now that they have its attention at the level of the Court and, for that matter the UN (in respect of Sudan at least), they protest about too much interest in the myriad challenges confronting the continent.

\section{Some Key Challenges for the ICC-Africa Relationship}

There are broadly two types of challenges for the ICC and Africa as they seek to build a solid and mutually beneficial relationship for the furure. Though they overlap, I have grouped them into two categories: legal and political. Generally, as we shall see in due course, some of these are not issues unique to the Court and its relationship with the continent. Rather, they concern the nature of international criminal law and the growth of the ICC as a new institution. This is partly because the international criminal justice regime centered on the Court is still

131) For an in-depth discussion and the relevant statements and documents, see UN, The United Nations and Rwanda: 1993-1996 (UN Blue Books Series, Vol. X, New York: Unired Nations, Dept. of Public Information, 1996) at 42 and 266-267.

132) The United Nations and Rwanda, supra note 131, at 46 and 273. 
new, and aspects of it are still widely misunderstood or contested by differently situated groups, actors and interests.

An additional complication may arise from the reality that the new international criminal law occupies terrain previously hegemonized by sovereignty which, in turn, structured the Westphalian international legal order that exists today. As sovereignty's hegemony is contested, new actors, hitherto non-players at the international level, seek to make their voices heard. In this environment, nascent international institutions such as the ICC, which are at the front-line of international society's battle to roll back certain aspects of sovereignty, may open themselves to criticism. Criticism is not in and of itself bad, provided that it is constructive. The Court, as a new body, should embrace the constructive criticism that it receives and, to the extent possible, address it. This will help establish its credibility and legitimacy as a serious player in the international arena. In this regard, the ICC, like other multilateral treaty-based international organizations, such as the World Trade Organization which belatedly realized this after the Doha Round of negotiations stalled because developing country concerns were largely ignored, should be mindful that, in the long term, it would not be in its best interests to ignore legitimate concerns of the majority of its State Parties. This is so in relation to a host of issues, but especially questions about the timing and sequencing of prosecutions, vis-à-vis peace negotiations, which will no doubt arise in future situations.

\subsection{Legal Challenges}

Some of the current tension between the ICC and Africa has been exacerbated by the emergence of new legal principles whose implications remain uncertain. Some of these relate to controversies emanating from the maiden application of the Court's internal legal framework, primarily the Rome Statute, to African situations, while others betray concerns about some seemingly unsettled principles of international law more generally. In some cases, the former are moulded by the latter and vice versa. Overall, these issues tend to put the ICC under the spotlight of criticism within and outside Africa, at times, specifically calling into question the propriety of certain decisions taken by some of its principal officials. This section of the article will examine a number of these legal issues. In highlighting them, I suggest that the more these uncertainties are settled, the less controversial ICC actions on the continent will likely become. In turn, African countries are more likely to reinvest seemingly lost confidence in the Court's legal regime and to rely on it to address the current accountability gap.

\subsubsection{State consent and ICC jurisdiction over nationals of non-parties}

In the first group of concerns are general issues of jurisdiction which feature prominently now similar to the way they did during the years leading up to the 
adoption of the Rome Statute. In this respect, a particularly contentious point has been whether the ICC can assert jurisdiction over the nationals of nonparties. This problem flows from a primary rule of international law under which consent is the basis for states' assumption of international obligations. This norm is well established in customary international law and is underscored by the VCLT. ${ }^{133}$ The issue of "State consent" was hotly debated during the Rome negotiations, and again, has resurfaced in the context of the Security Council referral of Sudan to the Court. ${ }^{134}$ Some countries, including the affected state, have argued that the ICC's assertion of jurisdiction was a violation of its sovereignty. This may be a good political argument. But it is not as firmly grounded in the law as might first appear. Why?

Under the Rome Statute, the Court's jurisdiction can extend over the nationals of a non-party like Sudan in three limited circumstances. ${ }^{135}$ First, where the crimes are committed by a national of a non-party within the territory of a State Party - which is obviously not the case here. ${ }^{136}$ Second, where the non-party decides to lodge a declaration accepting the ICC's exercise of jurisdiction (again not applicable to the Sudan situation). ${ }^{137}$ Third, where the Security Council, acting under Chapter VII of the UN Charter, refers a non-party situation to the Prosecutor in accordance with Article 13(b) of the Rome Statute. Through admittedly limited practice, this power to adopt measures aimed at restoring international peace and security is now said to include creating special tribunals to prosecute international crimes - as was done in relation to the ICTY and ICTR in the early nineties. Be that as it may, states are deemed to have expressed consent to such coercive action based on the binding nature of Article $39 .{ }^{138}$ Sudan, like other UN Member States, had accepted to implement such decisions pursuant

133) That foundational convention notes, inter alia, that 'the principle of free consent' is 'universally recognized'. See VCLT, supra note 17 , preambular para. 3 .

134) Ironically, this power to assert jurisdiction over nationals of non-parties is one of the major factors that led the United States to refuse to sign on to the Rome Statute at its adoption in Rome in July 1998. Just years later, it participated in Security Council debates that led to a referral under which that very argument was deployed to ground ICC jurisdiction against another state (Sudan). It only abstained from the vote, having secured an immunity exception from ICC jurisdiction for its peacekeepers. See D. J. Scheffer, 'The United States and the International Criminal Court', 93 American Journal of International Law (1999) 14; $R$. Wedgwood, 'The International Criminal Court: An American View', 10 European Journal of International Law (1999) 93-107.

135) For an excellent analysis, see $D$. Akande, "The Jurisdiction of the International Criminal Court over Nationals of Non-Parties: Legal Basis and Limits', 1 Journal of International Criminal Justice (2003) 618-650.

136) Art. 12(2) (a) ICCSt (Preconditions to the exercise of jurisdiction).

137) Art. 12(3) ICCSt (Preconditions to the exercise of jurisdiction).

138) Art. 39 of the UN Charter provides: The Security Council shall determine the existence of the any threat to the peace, breach of the peace, or act of aggression and shall make recommendations, or decide what measures shall be taken in accordance with Articles 41 and 42, to maintain or restore international peace and security. 
to Article 25 of the UN Charter. As the Security Council's referral is based on Chapter VII authority and Article 13(b) of the Rome Statute, this is not as valid a criticism of the ICC.

Still, this answer remains somewhat unsatisfactory in that a strong argument can be made that the use of this power to assert criminal jurisdiction could not have been contemplated when Sudan signed on to the UN Charter. ${ }^{139}$ One might even challenge whether such a far reaching and highly intrusive power would have been voluntarily ceded by new and sovereignty conscious states, surfing the high waves of nationalism and decolonization, to an international organization in the immediate aftermath of World War II. This is particularly so considering that almost all those same states put the idea of a permanent penal court on hold for almost 50 years. Furthermore, when they finally warmed up to it, they felt it necessary to negotiate a new multilateral treaty to establish such a tribunal, instead of creating one through an amendment of the UN Charter. They certainly did not also choose to authorize the Security Council to so do on their behalf using its extraordinary Chapter VII authority.

Secondly, the power to assert such jurisdiction is being invoked in the face of persistent objections by the relevant state (Sudan), which is reported to have even contemplated withdrawal from the post-world War II UN collective security regime to undercut the Court's claim to jurisdiction through the Security Council. ${ }^{140}$ This has obviously not transpired. But it does illustrate how far some third states might be willing to go to register their fundamental disagreement with ICC's extension of criminal jurisdiction over their nationals in what to them may appear tantamount to a wholesale re-writing of the fundamentally consensual basis of international treaty law.

Thirdly, besides questions of legality, the legitimacy of the use of the Chapter VII power in a criminal process intended to address individual accountability for serious international offences might be further queried considering the clearly undemocratic nature of the Security Council, which is composed of an elite group of five permanent and 10 non-permanent members. Though hardly representative of the main regions of the modern post-Cold War world, each of the five permanent members wield tremendous power including the ability to veto decisions supported by all of the other 14 members.

\subsubsection{ICC Jurisdiction over a Sitting Head of State}

A second and related set of legal controversies is about the Court's competence to issue an arrest warrant for a sitting president of a non-party like the Sudan. It is

\footnotetext{
139) In fact, Sudan, like many other African countries, was a British colony until 1 January 1956. It therefore only became a UN member on 12 November 1956.

140) W. Ali, 'ICC counsel criticizes Sudan handling of Bashir indictment', Sudan Tribune, 3 August 2008.
} 
also uncertain what the legal obligations are for States Parties in respect of enforcement of such a warrant, the provisions mandating cooperation under the Rome Statute such as Articles 86 and 98(1) and general customary international law. Furthermore, what, if any, are the consequences of a Security Council referral on the immunities that accrue to President Bashir?

The ICJ, in the famous Arrest Warrant Case (2002), held that serving heads of state enjoy absolute immunity from prosecution in foreign national courts. ${ }^{141}$ However, it also found that they may be prosecuted by certain international tribunals, for instance the ICC, where they possess jurisdiction. ${ }^{142}$ Nevertheless, as Akande has suggested, this general position should be read in light of two further conditions. ${ }^{143}$ First, that the instrument (in this case the Rome Statute) abrogates the immunity. Second, the concerned state is bound by that instrument. While the first condition is easily met by Article $27(2)$ which denies immunity to serving officials, the second might not because Sudan, to which the immunity attaches, would likely continue to enjoy them under customary international law. ${ }^{144}$

As Sudan came under the jurisdiction of the Court because of the Security Council referral, the crucial question is whether it in effect terminated Bashir's immunity. Neither the Rome Statute, nor the referral resolution sheds any light on the issue. The ICC Pre-Trial Chamber, which approved the arrest warrant in March 2009, glossed over the matter in a terse two-page discussion in which it found that his current position as Head of State had no effect on the Court's exercise of jurisdiction over his case. ${ }^{145}$ Yet, it had already been suggested by commentators that by fiat of the Chapter VII resolution, the immunity may have been lifted either through the referral resolution's specific decision in operative paragraph 2 that the Government of Sudan shall "cooperate fully with" the ICC, or alternately, on the basis that the mere referral of the situation automatically bound Sudan as if it were a party to the Rome Statute, including the provision abrogating immunities. ${ }^{146}$ Without saying so, the latter approach appears to have been implicitly endorsed by the pre-trial judges. ${ }^{147}$

141) Case Concerning the Arrest Warrant of 11 April 2000 (Democratic Republic of Congo v. Belgium), Judgment, 14 February 2002, para. 58.

142) Arrest Warrant (2002) Judgment, para. 61.

143) D. Akande, 'The Bashir Indictment: Are Serving Heads of State Immune from ICC Prosecution', Oxford Transitional Justice Research Working Paper Series, 30 July 2008 at 2.

144) Akande, ibid., at 2.

145) Decision on the Prosecution's Application for a Bashir Arrest Warrant, supra note 79, at paras. $41-45$.

146) Akande, supra note 143 , at 2.

147) Decision on the Prosecution's Application for a Bashir Arrest Warrant, supra note 79, at para. 45 (finding that the Security Council, by referring Sudan, 'accepted' that investigations and prosecutions arising therefrom will be conducted under the statutory framework provided for in the Court's primary and secondary legal instruments). 
The first suggestion is relatively more persuasive. Among the difficulties of the latter are these. First, a strong argument can be made that for the Security Council to revoke as fundamental a right as that of the immunity of a serving president, which immunity accrues to the benefit of the state (Sudan) as opposed to the person occupying the office (Bashir), the referral resolution would have to explicitly nullify that immunity. If this is so, it presumably would be easy to resolve the problem as there is nothing to stop the adoption of a further resolution eliminating that immunity. Were this to happen, an interesting question would be the legal effect of any objections that Sudan might make to such a resolution in relation to the immunity question and its intersection with the obligations of states not party to the Rome Statute.

A second objection could be that while the Security Council is competent to adopt measures aimed at restoring international peace and security, it does not possess the power to unilaterally impose treaty obligations upon a state. The UN Charter does not expressly give it such powers. One might then argue that the abrogation of Sudan's immunity is an implied power necessary for the performance of its peace maintenance functions. Without wading into controversies about the extent and limits of implied powers doctrine as developed by the ICJ, it is certain that the UN and its various organs are bound to act in accordance with the principles and purposes of the organization outlined in their founding charter and within the confines of international law. Regarding Sudan (which is a signatory to the Rome Stature), if it is true that the effect of the resolution is to import all the obligations therein, it can be cogently argued that the Security Council would be effectively imposing or substituting the missing ratification. That would undermine the consensual basis of international treaty law and is likely to be untenable. Similarly, it is undisputed that Article 103 of the UN Charter gives precedence to the treaty establishing the UN and would override any obligations under another international agreement. Nevertheless, it is of little assistance here because Sudan has obviously not yet assumed any such obligations. In the circumstances as well, it would be highly surprising if it did so in the near future. ${ }^{148}$

On the other hand, it has been argued that Security Council practice which paved the way for the ICTY to try President Slobodan Milosevic and the ICTR to convict Prime Minister Jean Kambanda, because of the Chapter VII resolutions creating those tribunals, abrogated immunities. ${ }^{149}$ However, those situations appear to be distinguishable from the Sudan scenario. The relevant countries

\footnotetext{
14*) This argument was inspired by a similar one made in relation to a Chapter VII resolution adopted by the Security Council, which purported to bring into force the Statute of the Special Tribunal for Lebanon. See B. Fassbender, 'Reflections on the International Legality of the Special Tribunal for Lebanon', 5 Journal of International Criminal Justice (2007) 1090-1 105, at 1098.

149) Akande, supra note 143 , at 3 .
} 
did not seem to object to the nullification of the immunity. This should not be surprising. Milosevic, who was discredited domestically, lost power to the opposition. In fact, this enabled his surrender for trial. In the case of Rwanda's Kambanda, he was no longer in office at the time of his indictment and conviction. With the Hutu genocidal regime that he presided over having lost the war and on the run, the new mostly Tutsi-led government composed largely of former enemies had no other interest but in Kambanda's arrest and prosecution on pain of the death penalty. It was therefore the most unlikely to argue for immunity in his favor.

The fact is that we are here dealing with a head of state still holding office. It should be expected that Sudan's general objection that its sovereignty is being violated because it is not a party to the Rome Statute will be raised on the immunity question as well - as self-serving as it may be for Bashir to make it. Nevertheless, even if we take it for granted, as the Pre-Trial Chamber appears to suggest - albeit "without prejudice to a further determination on the matter" 150 - that the Chapter VII referral is sufficient legal basis for the Court to order Bashir's arrest for alleged international crimes irrespective of any immunities that Sudan may enjoy under international law, it is of concern but still perhaps too early to tell what the practical implications would be for international relations - as the AU has argued. In the face of such uncertainty, one effect we will likely see is for pro-ICC states, for example within the European Union, to refuse to receive the Sudanese President on their territory as a matter of policy thereby limiting his freedom to travel. Similarly, we may see other states, including those that are not necessarily as enthusiastic about international criminal justice, also restrict or deny visits from the indicted leader to avoid the embarrassment of non-compliance with their international legal obligations under the Rome Statute and the customary international law of immunities. Whatever the case, the jury is still out on the fundamental question whether the Security Council is any better positioned than States to do more than trigger the jurisdiction of the Court through referral of a situation to the Prosecutor.

\subsubsection{The ICC, "Self-referrals" and their Implications}

A third legal challenge for the ICC arose from its first referral from Uganda. Scholars questioned whether such "self-referrals" were contemplated and permissible under the Rome Statute. ${ }^{151}$ The Prosecutor stated a preference for them as they underscored the existence of the requisite political will to cooperate by the

150) See Decision on the Prosecution's Application for a Bashir Arrest Warrant, supra note 79, at para. 41.

isi) W.A. Schabas, 'First Prosecutions at the International Criminal Court', 25 Human Rights Law Journal (2006) 25-40, at 8 and 18-19 (arguing that the drafting history of Art. 14 demonstrates that self-referrals were not contemplated; that historical and logical reasons militate against permitting self-referrals; and that the ICC Prosecutor effectively allowed Uganda to 'jump the queue' vis-à-vis the 100 or so other States Parties to the Rome Statute). 
referring state. Schabas, a leading commentator, subsequently observed that ratification may well be the ultimate indication of political will. ${ }^{152}$ On the other hand, Gaeta suggests that self-referrals, while not without some pitfalls, appear to be a better option in comparison to referrals activated by third states or even cases developed using the proprio motu prosecutorial power. ${ }^{153}$ Kress went even further to argue that self-referrals may be reconcilable with State Party obligations if they are understood as broadly requiring that a state take genuine steps to investigate and prosecute crimes, irrespective of whether it chooses to do so itself or through extradition to another state or even by way of surrender of its jurisdiction to an international criminal tribunal. ${ }^{154}$

Taking a long-term perspective, it appears that there has not yet been sufficient practice to reach firm conclusions on the propriety, or lack thereof, of self-referrals. Nonetheless, some of the States Parties to the treaty, as well as the Prosecutor, have all interpreted the provisions of the Rome Statute as permitting such referrals and the judges have, by admitting those cases, endorsed this interpretation. This may be an important step forward given how reluctant states generally are to bring human rights complaints against other states before international adjudication mechanisms. Of course, here the nuance is that they are not referring others, only themselves. Nevertheless, the habit of making self-referrals may well start to spill over into referrals of other states - presumably in situations where the complainant state stands to benefit in the outcome.

At the same time, once a referral has been made by a party, the Prosecutor was correct to treat it as applicable in respect of the whole situation instead of, as referring states like Uganda would have it, the crimes only allegedly committed by its adversary - the LRA. But for the so-called policy of "symmetric interpretation" of referrals, the ICC objective of ending impunity would be seriously undermined because it would have allowed states to essentially "hijack" the Court to go after their enemies while their armed forces escape any form of international accountability. ${ }^{155}$

An additional concern meriting consideration is the question whether the referring state can claw-back on a referral and reassume primary jurisdiction. This is what Uganda has since tried to do in an attempt to reach a compromise with the LRA. The answer will likely have to turn on the facts of each situation. Even so, at a general level, it is clear both from the letter and spirit of the preamble and substantive provisions of the Rome Statute, and indeed the purpose of the ICC as a whole, that states have a primary obligation to prosecute serious international crimes. The regime of complementarity is the centre-piece of this logic. In this

152) Ibid., at 18-19.

153) Gaeta, supra note 15, at 950-951.

154) Kress, supra note 15 , at 946.

155) Gata, supra note 15, at 950-951. 
light, it does not appear to be a stretch to argue that a claw-back should be possible, ideally in consultation with the Prosecutor, and consistent with Articles 17, 18 and 19 of the Rome Stature. This assumes, of course, that the State Party would be acting in good faith, perhaps in response to a significant change of circumstances or for other legitimate reasons, and that it is willing and able to prosecute under Article 17. Preferably, disagreements over such issues would be presented to, and ultimately resolved by, the judges of the Court.

\subsubsection{Selection of Indictees and the Hiccups of the First (Lubanga) Trial}

Another legal challenge for the ICC is the criticism regarding the Prosecutor's selection of indictees. It was rightly argued that states are the jurisdictions of first resort. So, in the case of Lubanga who was apparently in jail in DRC for alleged crimes there, the country seemed to have taken at least some steps to fulfill its obligation to prosecute him through its national courts. ${ }^{156}$ It was consequently incorrect for him to be incarcerated for a long period and then transferred from jail into ICC custody, ostensibly because he had allegedly committed the more heinous crime of child recruitment to justify international takeover of the case. This led one commentator to conclude that the Court may have unwisely thrown caution to the wind in its eagerness to secure a first case. ${ }^{157}$

To be fair, the DRC situation came to the Court by way of a self-referral. However, this concern about its exercise of jurisdiction over Lubanga remains valid because there is no obligation on the Prosecutor under the Rome Statute to accept a referral following the conduct of his own independent investigations. Even where he accepts a self-referral, he is also equally free to determine, based on the evidence he has gathered, those persons he deems "most responsible" for a possible prosecution for genocide, crimes against humanity and or war crimes. This would surely include the power not to indict those already under genuine prosecution under national processes.

Furthermore, the Prosecutor's handling of the Lubanga case did not help the ICC's reputation. The trial finally started in The Hague in early 2009. While the kinks usually associated with first cases in international criminal proceedings will hopefully be worked out, the Trial Chamber felt compelled in 2008 to stay the proceedings and to order the Accused's release. ${ }^{158}$ The judges found that a fair trial

\footnotetext{
156) Schabas, 'First Prosecutions', supra note 151 at $28,30,31$.

157) Ibid. at 38.

158) Prosecutor v. Thomas Lubanga Dyilo (ICC-01/04-01/06), Trial Chamber I, 'Decision on the Consequences of non-disclosure of exculpatory materials covered by Article 54(3)(e) agreements and the application to stay the prosecution of the accused, together with others issues raised at the Status Conference on 10 June 2008', 13 June 2008; 'Decision on the release of Thomas Lubanga Dyilo', Trial Chamber I, 2 July 2008 and 'Decision on the request of the Prosecutor for suspensive effect of his appeal against the "Decision on the release of Thomas Lubanga Dyilo", Appeals Chamber, 7 July 2008.
} 
would be impossible because the Prosecutor had entered into confidentiality arrangements with third parties and consequently failed to disclose significant potentially exculpatory material to the defence. They reasoned that this had "ruptured" the trial process to such a degree that it was "impossible to piece together the constituent elements of a fair trial." 159 The Appeals Chamber agreed, but in light of new developments enabling disclosure, remitted the case back to the trial judges for reconsideration. ${ }^{160}$ The stay was subsequently lifted by the judges who found a change of circumstances. ${ }^{161}$

Lubanga has suffered significant delays between his arrest and start of trial, partly because of prosecutorial decisions on the conduct of investigations and evidence collection. Contrary to popular commentary at the time, however, the ruling may be a positive sign given all that it suggests about the independence of the judges in their work. From a long-term view, their abuse of process decision, in which they demonstrated that they would even dismiss the symbolically important first case to ensure fair trial guarantees, may prove to be the saving grace for the legitimacy of the Court in respect of the maiden case and indeed the larger fledgling tribunal.

\subsubsection{Justice. But for Whom?}

A further issue that has been debated, animated by developments in the Taylor case at the SCSL, is the question whether the ICC should be holding trials in Europe for crimes alleged to have been committed by Africans against other Africans within Africa. It should be obvious that such far away trials will cost more money. However, a bigger problem has been whether the victim communities would not be deprived of an opportunity to see the trial process unfold first hand. Is remote justice effective?

This is a question that will have to be addressed by the Court once it has more than a single trial underway. In this regard, the idea of holding hearings of cases in the Africa region, which is apparently supported by some of the ICC judges, may be logistically difficult to execute keeping in mind security and cost considerations. Nevertheless, if done, it would likely go a long way to bridge the growing emotional distance between the Court and many of its supporters in Africa. It will no doubt help boost the legitimacy of the ICC in the eyes of the people of the continent.

\footnotetext{
159) Decision on the Consequences of non-disclosure of exculpatory materials, ibid., at para. 93.

1(xi) Prosecutor v. Thomas Lubanga Dyilo (ICC-01/04-01/06), Appeals Chamber, 'Judgment on the appeal of the Prosecutor against the decision of Trial Chamber I entitled "Decision on the consequences of non-disclosure of exculpatory marerials covered by Article 54(3)(e) agreements and the application to stay the prosecution of the accused, together with certain other issues raised at the Status Conference on 10 June 2008"', 21 Ocrober 2008.

161) Prosecutor v. Thomas Lubanga Dyilo (ICC-01/04-01/06), Trial Chamber I, 'Reasons for Oral Decision lifting the stay of proceedings', 23 January 2009.
} 


\subsection{Political Challenges}

\subsubsection{ICC-Style Justice Crowds out Possibilities for Peace and Reconciliation}

There are obviously many political challenges facing the ICC as it goes through growing pains. Only three of the more significant ones are considered in this article. In relation to Africa, a key controversy that the Court will have to confront, if governments on the continent are to continue backing it, is the perception that the legal tool is too blunt an instrument for use in all situations. In this regard, the ICC has already been criticized for allegedly standing in the way of a peace agreement between belligerents in places such as Uganda. The argument on this matter tends to come in two shades.

First, it is said that the African attitude towards justice emphasizes reconciliation rather than the kind of retribution that the criminal law engenders. ${ }^{162}$ In this regard, it may in some situations be better for enemies to bury the hatchet and allow the society to move on, especially where a military victory has proved impossible - as is often the case in rebel insurgencies. This decision in turn entails a give and take that normally includes some provision for a form of forgiveness, apology or amnesty - as bitter as that pill maybe to swallow. Such an approach also permits for deployment of local or traditional forms of justice that may be more aligned with African traditions. ${ }^{163}$ Liberia, Uganda, Rwanda and even post-apartheid South Africa are usually invoked to illustrate the force of this argument. ${ }^{164}$

Second, a negotiated end to hostilities is not only a desirable option in some instances, it is the pragmatic, if not the only, option to avert further catastrophe and international humanitarian law violations. This argument becomes one about both what has happened in the past as well as what might happen in the future. To what extent is there responsibility to address crimes of the past while working to prevent other imminent ones in the future? It also inevitably becomes a question about the ownership of the choice. Does the Court, or for that matter any distant international institution, possess the legal and moral right to make such far reaching decisions for war-battered African communities?

On this issue, the example usually offered is that of the northern region of Uganda which has experienced a tragic low-intensity conflict for decades thereby constituting one of Africa's major human rights tragedies. Can those communities where the direct victims of war reside in displaced or refugee camps choose to prioritize peace instead of justice? Or to prioritize peace now and aim to do

\footnotetext{
162) M. Palayiwa, 'What's the ICC up to?', 43 New African (May 2009) 16-20, 20.

163) Buteera, supra note 108, at 63-64.

164) In relation to Rwanda, reconciliation is encouraged through the traditional gacaca process though only in respect of lower to middle ranking perpetrators. The highest ranking genocidaires, i.e. those at the level that would attract ICC interest, are tried in regular criminal trials.
} 
justice later? Does it matter that the crimes in issue are not local crimes, that they are crimes against all of humanity? In other words, does the mere qualification of the crimes under discussion as international offences raise them to a threshold beyond the purview of the local community because of the more pressing international community interest? ${ }^{165}$

There are obviously no easy answers to such fundamental questions. None are hazarded here. At the same time, one may observe that part of the difficulty is the irony that those in the ICC and international institutions laying claim to the right to make such decisions, ostensibly on behalf of the victims, would often have never experienced any war and its psychological and other impact on a population. We therefore end up in a paradox where, supported by the armchair activism of some cheerleader Western human rights NGOs, officials such as the Court's Prosecutor take entrenched positions - apparently in the name of the victims. Sometimes, those positions are seen as not necessarily consistent with the immediate needs and realities of those particular communities in Africa. This argument is currently being used in discussions about the humanitarian situation in the Sudan, especially in respect of the victims of the hostilities in Darfur.

This sort of debate has led to concerns about the kinds of decisions being taken by the Prosecutor and raised uncertainty regarding whether or not he is properly exercising his discretion. ${ }^{166}$ One response could be that he is "independent". Thus, he should have unfettered ability to decide what to do in a situation once he has been invited to investigate heinous crimes. But that response goes only so far to resolve the issue and leaves unsettled issues of perception and legitimacy, both of which are important for a new international court of law mandated to deliver deliberate, instead of "cow-boy", justice.

In addition, while the independence of the prosecutorial power is important and should be closely safeguarded, the basis for it is the rejection of any improper interference in its exercise. However, the scope for exercise of such discretion at the level of the Court is much narrower than might first appear. This is so considering the extensive limitations on the prosecutorial power carefully negotiated by states and incorporated into the Rome Statute. These include use of provisions to enable challenges to admissibility, preliminary judicial rulings on admissibility of cases brought before the Court and even contestations about his assertions of jurisdiction under Articles 17 to 19 of the Rome Statute. Those provisions generally affirm that the ICC, of which the Office of the Prosecutor is but one organ, is and was intended to defer to genuine efforts to prosecute international crimes at the national level.

\footnotetext{
(65) Palayiwa, supra note 162, at 20.

160) For a fine treatment of the notion of prosecutorial discretion at the ICC, see A.M. Danner, 'Enhancing the Legitimacy and Accountability of Prosecutorial Discretion at the International Criminal Court', 97 American Journal of International Law (2003) 510-552.
} 
On the flip side, the Rome Statute provides scope for review of prosecutorial decisions not to initiate an investigation, or once initiated, a decision not to prosecute under Article 53(1)(c) and (2)(c). Indeed, Article 53(3)(a) and (b) permits a referring state and even the Security Council to initiate review of a decision not to pursue a matter. In addition, a pre-trial chamber may, on its own initiative, conduct such a review. Of particular significance here is Article 53(4) which gives the Prosecutor the opportunity to reconsider, at any time, a decision whether or not to initiate an investigation or to prosecute based on new facts or information.

Even beyond this provision, however, it is arguable that the exercise of discretion in law must be subject, or at least amenable, to some form of judicial review where the decision taken leads to patently unreasonable results. In this context, it may be that at later stages, the pre-trial and trial chambers of the ICC may be seized of review challenges to the use of the prosecutorial power by states, accused persons or even victims, for example, under Article 53 of the Rome Statute.

\subsubsection{The "Double Standard" and U.S. "Exceptionalism"}

But perhaps the biggest political challenge for the Court at this juncture, especially in relation to its legitimacy in Africa, is the "double standard" problem. The idea that everyone is equal before and under the law underpins domestic legal systems, especially in the area of criminal law. The position under international law in relations between states is no different, at least in theory. This is enshrined in the preamble and Article 2(1) of the foundational UN Charter which affirm the "equal rights of men and women and of nations large and small" and the "principle of sovereign equality of all" states.

Essentially, as all human rights lawyers know, the principle of equality, whether of individuals or of states, does not admit of arbitrary distinctions in respect of its application based on states' or individuals' social, wealth, moral or other status. The ideals of that principle seem to have clashed with Africa's sense of justice in the face of current U.S. exceptionalism towards the Court. ${ }^{167}$ In fact, the irony is not lost on African countries that as a major power, the U.S. and two other states (China and Russia), all of which are not parties to the Rome Statute, sit comfortably at the centre of a Security Council process that referred Sudan to the ICC for investigations and possible prosecutions in March 2005. This in itself would ordinarily be perceived as problematic even without any allegations that the Bush Administration oversaw, or was at least permissive towards, war crimes in the context of hostilities in Afghanistan and Iraq in 2002 and 2003.

167) For an overview of the core issues, see W.A. Schabas, "United States Hostility to the International Criminal Court: It's All About the Security Council', 15 European Journal of International Law (2004) $701-720$. 
As David Scheffer, former U.S. Ambassador-at-large for War Crimes, and others have argued:

US exceptionalism may have a place in international politics, but this concept has run its course in the sphere of international criminal justice. No nation should ignore its duty to bring war criminals to justice or otherwise shield its own leaders or soldiers from charges of genocide, crimes against humanity, or war crimes. ${ }^{168}$

Though not of the Court's making, key features of U.S. exceptionalism that are creating, or reinforcing, negative perceptions of international criminal justice in Africa and in the Third World are the following aspects of superpower policy.

First, the U.S. supports ad hoc international tribunals by funding them - a policy adopted under the Clinton Administration and that arguably goes as far back as Nuremberg and Tokyo. But the recent crop of the country's leaders have allegedly overseen the commission of human rights violations, including crimes as heinous as torture and disappearances, in Iraq (Abu Ghraib) and Cuba (Guantanamo Bay). This has occurred under cover of the "War on Terror". Guantanamo, as numerous independent human rights bodies have claimed, became a "rightsfree" zone. ${ }^{169}$ Yet, no one, not even the ICC, threatens to prosecute the American military or political leaders involved.

Those who advocate such prosecutions often fail to take into account that the U.S. is not a party to the Rome Statute. Nonetheless, as we saw earlier, it is possible for the ICC to assert jurisdiction in respect of non-parties and their nationals in limited instances, especially through a Security Council referral. However, this is highly unlikely to lead to prosecution of American leaders because of the veto power conferred on the permanent members, including the U.S., as well as her allies Britain and France. The current political reality makes it impossible for African countries to imagine a scenario where the U.S. would be referred to the Court by the Security Council. To already skeptical critics, this becomes a form of reaffirmation of the skewed nature of global politics and the selectivity of international criminal law. Issues of justice have thus become mired in, and some might even say held hostage by, big power politics. The knock on effect has been a blurring of the crucial distinction between international law and international politics if the project of global justice is to flourish and gain global legitimacy.

In any case, matters were exacerbated by Prosecutor Moreno-Ocampo's decision not to apply for authorization to investigate possible international crimes in Iraq even though some of the belligerents there, such as the United Kingdom, are

\footnotetext{
${ }^{1(6) 1}$ Scheffer et al., supra nore 96.

(16) See, e.g., Center for Constitutional Rights, Report on Torture and Cruel, Inhuman, and Degrading Treatment of Prisoners at Guantanamo Bay, Cuba (New York: CCR, 2006) (quoting a U.S. military intelligence officer telling prisoners 'You are in a place where there is no law - we are the law.').
} 
parties to the Rome Statute. Indeed, in February 2006, he publicly notified that he had received many complaints regarding the Iraq situation but that he had no competence to prosecute the crime of aggression (which is yet to be defined). ${ }^{170}$ Moreover, curiously relying on information partly furnished by British authorities, he also concluded that there were no reasonable indicia of elements of genocide, crimes against humanity and war crimes and, importantly, that the requisite gravity threshold had not been achieved. By comparison, one might query how this threshold was achieved in the CAR situation despite the low number of reported victims there over a two-year period. In any event, the belligerents in Iraq were not parties to the Rome Statute. In Africa and indeed other parts of the developing world, as various commentators have observed, "few have been convinced by this official explanation". ${ }^{171}$

Second, the U.S. adopted domestic legislation precluding cooperation with the Court. The American Service Members Protection Act (2002) - the so-called "Hague Invasion Act" - provided a mechanism to penalize any country, including through military force, that dared to hand over a U.S. national to the ICC. ${ }^{172}$ This position was seen as outright bullying and as an attempt to undermine the universality of international criminal law. Nevertheless, the Court has not publicly expressed a position condemning it. While this is not to suggest that the ICC may not have its own private misgivings about the U.S. position, its silence, which is interpreted as acquiescence, is deafening to many people in Africa. This state of affairs bolsters, rightly or wrongly, those who argue that international criminal law is being used as a whip to discipline only weaker and poorer Third World states in impoverished continents like Africa, but not powerful states in the developed world - as President Kagame of Rwanda has suggested.

Third, during the Bush Administration, the U.S. forced many developing countries to sign Article 98 agreements wherein promises are made not to handover American nationals to the ICC without first securing its consent; the countries faced the prospect of losing all financial, military and humanitarian aid if they failed to sign what was dubbed by human rights activists as "Bilateral Impunity Agreements". ${ }^{173}$ While over 36 countries in Africa signed those agreements, a good number of mostly larger states on the continent, such as South Africa, refused to balk under the pressure. They lost much needed American

170) ICC Office of the Prosecutor, 'Statement on communication concerning the situation in Iraq', 9 February 2006.

171) Chitiyo and Devlin, supra nore 106, at 69.

172) Coalition for the International Criminal Court, Press Release, 'US Congress Passes Anti-ICC "Hague Invasion Act", 26 July 2002, online at: <http://www.iccnow.org/documents/07.26.02ASP AthruCongress.pdfs (visited 15 May 2009).

173) Coalition for the International Criminal Court, 'USA and the ICC: Bilateral Immunity Agreements', online at: <http://www.iccnow.org/?mod=bia> (visited 15 May 2009) and Human Rights Watch, 'Briefing Paper on Bilateral Immunity Agreements', New York, 20 June 2003. 
assistance. ${ }^{174}$ It is so far unclear whether that aid has been reinstated under the new Obama Administration.

Lastly, the U.S. has moved to block even initial suggestions at legal action implicating the conduct of its own leaders or allies in the courts of certain national jurisdictions. For example, the U.S. threatened Belgium after that country's national courts invoked universal jurisdiction to indict Defence Secretary Donald H. Rumsfeld and Israeli Prime Minister Ariel Sharon. The indictments were dropped and Belgian law changed after the U.S. apparently signaled it would advocate for the relocation of the NATO headquarters from Brussels to another state. ${ }^{175}$ Ironically, all this took place even as European courts, especially in France, Belgium and Spain, were flexing legally questionable muscle over high ranking officials in Rwanda and elsewhere based on expansive theories of universal jurisdiction. ${ }^{176}$

Again, while these are unilateral actions of a particular state instead of ICC decisions, they help to feed African allegations about bias and the selective nature of international criminal law. It also suggests the regime's amenability to political manipulation by big powers - whether before international or national criminal courts. In this vein, President Kagame has suggested that the people of the continent must ask the question: "Is it only the African involved in criminal activity?" To him, this issue is also about historical hegemonies. Taken to its logical conclusion, he urges all Africans to "fight this tendency for Europeans to always cast themselves in the role of judge and the African always as the guilty party." 177

The U.S. has insisted that it was merely looking out for its own national interests. Of course, its stance is expected to soften with the advent of the Obama Administration. There are already early signs of this as it now takes public positions defending the Court's decision to issue an arrest warrant for Bashir. It also condemned his expulsion of humanitarian aid groups from Sudan. ${ }^{178}$ Though it is unlikely that it will be acceding to the Rome Statute anytime soon, many

174) O. Bekou and S. Shah, 'Realising the Potential of the International Criminal Court: The African Experience', 6 Human Rights Law Review (2006) 499-544, at 537.

175) R. Brody, 'Belgium Curtails Anti-Atrocity Law Under U.S. Pressure', ACLU International Civil Liberties Report 2003, online at: <http://www.sdshh.com/ICLR/ICLR_2003/12_Brody.pdf> (visited 15 May 2009).

176) V. Thalmann, 'French Justice Endeavours to Substitute for the ICTR', 6 Journal of International Criminal Justice (2008) 995-1002.

177) S. Kanuma, 'I refuse to be a servant of the West', The East African, 22-28 December 2008 at p. 8 .

178) See, e.g., 'Statement by Ambassador Susan E. Rice, U.S. Permanent Representative to the United Nations, on the ICC's Arrest Warrant for Sudanese President Bashir', 4 March 2009, online at: <http://www.iccnow.org/documents/Statement_by_AmbassadorRice.pdfs and 'Statement by Ambassador Susan E. Rice, U.S. Permanent Representative to the United Nations on the Expulsion of Humanitarian Groups from Sudan', 6 March 2009, online at: <http://www.usunnewyork .usmission.gov/press_releases/20090306_043.html> (visited 15 May 2009). The U.S. Congress even recently passed a resolution commending the ICC for its issuance of the Bashir warrant. 
household name Western NGOs are so giddy that the superpower seems to be changing its stance on the ICC that they have ignored the harm being done to the Court by its increasingly damaged image in Africa.

Ultimately, the fact is that the ICC - as an institution - may not have much it can do about the U.S. policy towards it. But the foregoing undoubtedly reinforce the historic divisions between the North and South whereby powerful states are perceived as being let off the hook of prosecution while the weakest links are targeted in Africa. Indeed, in the wake of the Bashir arrest warrant, the Court has been accused of being fervently pro-Western in furthering the interests of American exceptionalism. Its apparent inability or unwillingness to confront the U.S. is seen as a hypocritical compromise coming at the expense of the universalist values of international law which it claims to espouse. ${ }^{179}$

African scholars like Mamdani have even suggested that after its initial opposition, the U.S. realized that it could turn the ICC into a "useful tool" to advance its interests. This is what it apparently proceeded to do. The Bush Administration moved, as part of this shift, from outright opposition to the world criminal court to a policy of "mutual accommodation" with it. In return, the Court has obliged by making policy decisions that either keeps it out of Washington's way or panders to it. ${ }^{180}$ To Mamdani, even in Africa, it is no accident that the ICC is only conducting investigations in four countries in which the U.S. has no particular interests or objections to the course charted by the Court.

Even more striking, in his view, is that there is a new "humanitarian order", of which the ICC is a part, whereby sovereignty is wrested away from poor nations by big powers. On this view, the responsibility to protect takes on imperialistic undertones as the Court is co-opted by the world's only superpower to target its adversaries, specifically the Sudan, while turning a blind eye to equally questionable actions by U.S. allies. Countries such as Rwanda and Uganda, which were both linked to the crisis in the eastern Congo, have benefited from the ICC's "pragmatic" policy of appeasement of the big powers. ${ }^{181}$

In assessing the validity of Mamdani's critique, a couple of points are immediately apparent. First, his is a political science analysis of the current ICC-Africa relationship. Second, such an analysis challenges us, as lawyers, to unpack controversial issues and therefore adds to our understanding of the complex and nonlegal factors that may be at work. However, from the perspective of international

179) Chitiyo and Devlin, supra note 106, at 69.

180) While Mamdani does not cite this in his article, influential American commentators have argued that even if the U.S. does not wish to become a party to the ICC for now, it 'needs the ICC to help it climb back into a position of global leadership.' Remaking its image as a credible 'friend of the ICC' was suggested as a way for it to influence the work of the permanent court to its advantage. See Scheffer et al., supra note 96.

181) Mamdani, 'Darfur, ICC and the New Humanitarian Order', supra note 70. 
law, his claims are open to serious criticism that they are exaggerated. In addition, his analysis was unfair for failing to show sensitivity to the history of how the four African situations came into the Court's purview, especially in respect of the Sudan hot potato which was essentially handed to it by the Security Council. Nor does it account, for that matter, for the apparent African participation in its creation or within the current decision making of its various organs. ${ }^{182}$ While it is anecdotally reported that the Prosecutor "encouraged" the Ugandan, DRC and CAR self-referrals, it remains true that the investigations into those situations were possible only because the relevant African states signed on to and ratified the Rome Statute. Those countries have also permitted and supported the ICC investigations that led to the various warrants of arrest. His claims would therefore have been significantly bolstered were they grounded in application of the relevant legal texts.

\subsubsection{The Depredations and Scars of Colonialism}

An additional challenge for the Court's achievements of its mandate in Africa has to do with the burden of history. As already alluded to, African countries are very conscious of and, some might say even scarred by, the depredations of colonialism. In the violent colonial encounter between Africans and Europeans that lasted for hundreds of years, international law did not only allow its language to be subverted by the cause of the big powers, it assisted by offering intellectual justifications for the mission civilatrice. Certainly, as Anghie and Chimni, two respected scholars in the so-called Third World Approaches to International Law (TWAIL) have argued, it was "principally through colonial expansion that international law achieved one of its defining characteristics: universality." 183 Indeed, TWAIL scholars show that international law was used to justify and legitimate the suppression of Third World peoples and therefore shaped the relationships of power and subordination inherent in the colonial order. To many of these scholars, colonialism was a key to the development of international law.

It follows that Africa and other formerly colonized societies must always be vigilant of the use to which international law, including international criminal

182) Concerns have been expressed by some African countries that the majority of ICC staff hail from other regions of the world. Nonetheless, there appears to be a sizable African contingent in the Court - at least at the senior levels. These include four judges (one of whom is the Vice-President), the Deputy Prosecutor, the Deputy Registrar, the Head of the Complementarity Division in the Office of the Prosecutor, the Senior Trial Attorney handling the Sudan file, the head of the Office of the Public Counsel for the Defence, a senior legal adviser in the Registry and various other lawyers in these and other units. In relation to the controversial Bashir warrant, it is noteworthy that a Ghanaian judge was strategically appointed to preside over the Pre-Trial Chamber that assessed the Prosecutor's application. In view of their roles, it is hard to argue that these officials are not partaking of the decisions taken by the Court. Even so, Africa is not as well represented in the offices of the ICC as much as it is in the dock.

183) Anghie and Chimni, supra note 118 , at 84 . 
law, can be put by powerful states. Mamdani's views would find more support here. Indeed, he has in fact suggested that the language of law has simply been subverted by the big powers to establish a "new humanitarian order". On this view, the global transition from the old system of sovereignty to a new humanitarianism confined to "failed" or "rogue states" has created a bifurcated international system whereby state sovereignty obtains in large parts of the world but is "suspended in more and more countries of Africa and the Middle East." He further decries the "emphasis on big powers as the protectors of rights internationally." This, he warns, is increasingly being twinned with the corollary belief that big powers should be "enforcers of justice internationally" - to the detriment of the weaker nations and their peoples. ${ }^{184}$ One need not subscribe to all these views to appreciate that, going forward, the challenges for the legitimacy of international criminal law will be many considering that the growth of the system will likely be shaped, or at least impacted by, the myriad interactions and inevitable collision of legal rules and external political imperatives and the governmental responses to them.

\section{Conclusion}

The Africa-ICC relationship currently appears to be confronted with some major challenges. However, because of the dynamism of international relations, that relationship will continue to evolve. In this regard, a number of tentative observations may be offered keeping in mind that it is still in its infancy.

To start with, African countries are showing an increasing commitment to addressing serious human rights abuses perpetrated by non-state actors within their territories. As part of this trend to fashion "African solutions to African problems", they have undertaken to make human security a priority for their people, including through conceptualization of an ambitious and unprecedented regional peace and security architecture with a legal mandate to take concrete steps, including military action, to anticipate and avert serious international crimes. This is significant given the reality that the doctrine of responsibility to protect has remained nothing more than a theoretical discussion in other parts of the world. In addition, it is because of reasons of self-interest and historical experience with untold atrocities that Africa early on supported the idea of the ICC; long before its birth - in fact, while in gestation in the belly of the international community. That support, as we saw, was displayed in the way the continent played an important role in the establishment of the Court. Since then, African

184) Mamdani, 'Darfur, ICC and the New Humanitarian Order', supra note 70. 
countries took the first crucial steps to refer situations to the permanent penal court for investigations.

Considering the current impasse between the AU and the ICC, it seems clear that the embattled continent has some strong and legitimate concerns about how international prosecutions may fit into its broader peacemaking and peace building objectives. In relation to the Sudan situation which has ignited substantial controversy that will likely continue, for example, the AU has reiterated that it is not opposed to prosecutions but that it is concerned about the timing of prosecutions. In this unprecedented area, some measure of controversy is perhaps inevitable. Still, concerns about the timing of prosecutions should not be discarded lightly by the ICC Prosecutor, as their effect on further loss of life and human rights violations may extend well beyond the realm of the legal to the humanitarian, political and economic.

In the long term, it should be recalled that African governments have urged the Sudanese authorities to take concrete steps to improve human rights conditions on the ground, all the while pressing for a comprehensive peace agreement between the warring sides. They have gone even further, in collaboration with the $\mathrm{UN}$, to deploy thousands of peacekeepers in the country thereby showing that they are willing to put their money where their mouths are. These are all important considerations that must be weighed by the ICC and the international community, though the full implications of the Bashir arrest warrant remain unclear at this stage. A humanitarian catastrophe could result. It could also propel Sudanese authorities to end their alleged support for militants committing crimes and perhaps lead to a measure of peace, if not a final resolution, of the Darfur conflict.

From the perspective of the Court, I have suggested in this article that there is presently emerging a fledging international criminal justice system of which it is the anchor. The ICC has a mandate to prosecute, as a tribunal of last resort, international crimes committed within national jurisdictions that are unwilling or incapable to do so. To some extent understandably, its work has so far focused on this aspect. Nevertheless, the Prosecutor must now start attending to the much harder task of engaging the prevention of further commission of international crimes, a core rationale of prosecutions - as reflected in the preamble of the Rome Stature. The prevention mandate is particularly important for the future success of the Court as an international institution since, as Moreno-Ocampo himself acknowledged, the number of cases prosecuted should not ultimately be the benchmark for gauging its success. In this regard, it is probably time for his office to shore up its programs to build national capacity to confront impunity, in line with the complementarity principle. When added to a serious outreach program in Africa, this will help to address the misinformation and distortions about the work of the ICC in a continent with low levels of literacy. Engaging directly and aggressively with African civil society will also help the Court to build bridges 
with the local populations and to make it more likely to achieve its justice goals on the continent.

At a more basic level, since my argument is about mutual gain and mutual vulnerability for both Africa and the ICC, the relationship between the Prosecutor and his African partners in the fight against impunity should not be allowed to stray, or worse, become antagonistic - as appears to be the case currently. The danger is that there may have already been a chilling effect to the Bashir warrant because the AU has requested that all 30 African States Parties to the Court convene at its headquarters in Addis Ababa, Ethiopia. The stated purpose of the meeting, apparently scheduled for early June 2009, was for those states to "exchange views on the work of the ICC in relation to Africa, in particular in the light of the process initiated against African personalities, and to submit recommendations thereon taking into account all relevant elements". ${ }^{185}$ There is a strong possibility that those discussions could lead to further political action that could be detrimental to the long-term interests of the Court as a young judicial institution.

Even if extreme action, such as a withdrawal of ratifications or referrals of one or more African States Parties is not taken, as anecdotal evidence suggests is likely, it may prod other countries from the continent to drag their feet in domesticating the Rome Statute. This is significant because out of 30 States Parties from the continent, only Kenya, Senegal and South Africa, have so far passed implementing legislation in Africa. Furthermore, other African States Parties may withhold their planned referrals, and signatories, their planned ratifications. It also will embolden countries, for instance Rwanda and Angola, which have vowed never to become part of the ICC to lobby other countries on the continent to their cause.

It is to be hoped that African leaders will in the end choose to register their disagreements about current prosecutorial practice within, instead of outside, the fledgling international criminal justice system anchored by the Court - whether through applications before the Chambers or through other policy action within the Assembly of States Parties. They will hopefully also unpack the false equation that the Prosecutor is equal to the ICC, and for that matter, the idea that absolute universal jurisdiction is equal to ICC jurisdiction. At the same time, the Court as a legal institution, whose very essence is to help build an international rule of law, must jealously guard its mission to ensure that it is not subverted, or perceived to have been subverted, as a pawn for Great Power use to merely target weak and or defeated adversaries in less influential regions of the world.

185) AU Assembly, Decision on the Application by the International Criminal Court Prosecutor for the Indictment of the President of the Republic of the Sudan (Dec. 221 (XII)), 3 February 2009, para. 5. 
